Prepared in cooperation with the Federal Emergency Management Agency

\title{
Flood of October 8 and 9, 2005, on Cold River in Walpole, Langdon, and Alstead and on Warren Brook in Alstead, New Hampshire
}

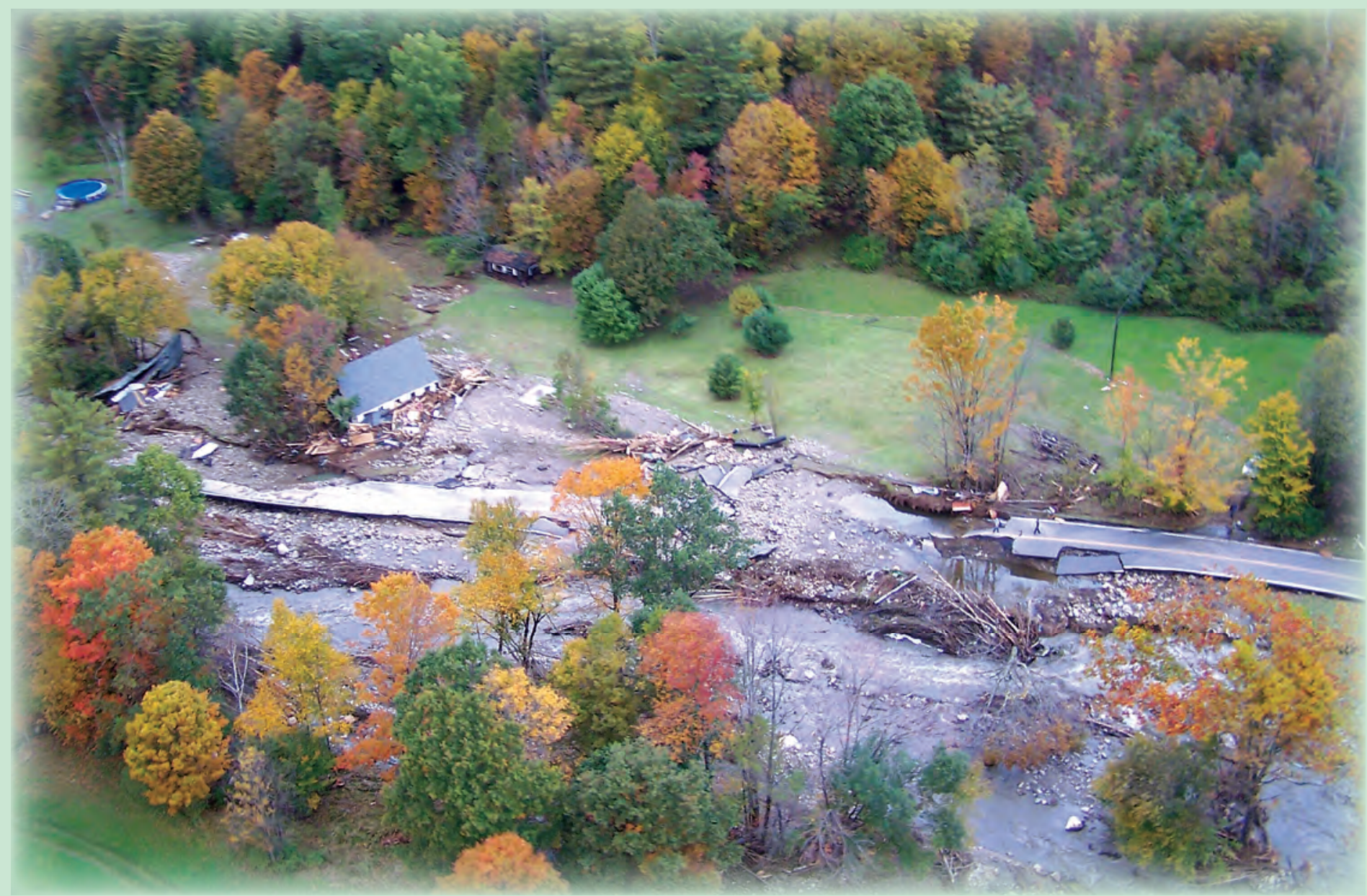

Open-File Report 2006-1221

U.S. Department of the Interior

U.S. Geological Survey 
Cover. Devastation along Warren Brook, Route 123 in Alstead, NH, after the October 8 and 9, 2005 flood. (Photograph courtesy of the New Hampshire State Police Aviation Unit) 


\section{Flood of 0 ctober 8 and 9, 2005, on Cold River in Walpole, Langdon, and Alstead and on Warren Brook in Alstead, New Hampshire}

By Scott A. Olson

Prepared in cooperation with the

Federal Emergency Management Agency

Open-File Report 2006-1221 


\section{U.S. Department of the Interior DIRK KEMPTHORNE, Secretary \\ U.S. Geological Survey \\ P. Patrick Leahy, Acting Director}

\section{U.S. Geological Survey, Reston, Virginia: 2006}

For product and ordering information:

World Wide Web: http://www.usgs.gov/pubprod

Telephone: 1-888-ASK-USGS

For more information on the USGS--the Federal source for science about the Earth, its natural and living resources, natural hazards, and the environment:

World Wide Web: http://www.usgs.gov

Telephone: 1-888-ASK-USGS

Any use of trade, product, or firm names is for descriptive purposes only and does not imply endorsement by the U.S. Government.

Although this report is in the public domain, permission must be secured from the individual copyright owners to reproduce any copyrighted materials contained within this report.

Suggested citation:

Olson, S.A., 2006, Flood of October 8 and 9, 2005, on Cold River in Walpole, Langdon, and Alstead and on Warren Brook in Alstead, New Hampshire: U.S. Geological Survey Open-File Report 2006-1221, 46 p., online only. 


\section{Contents}

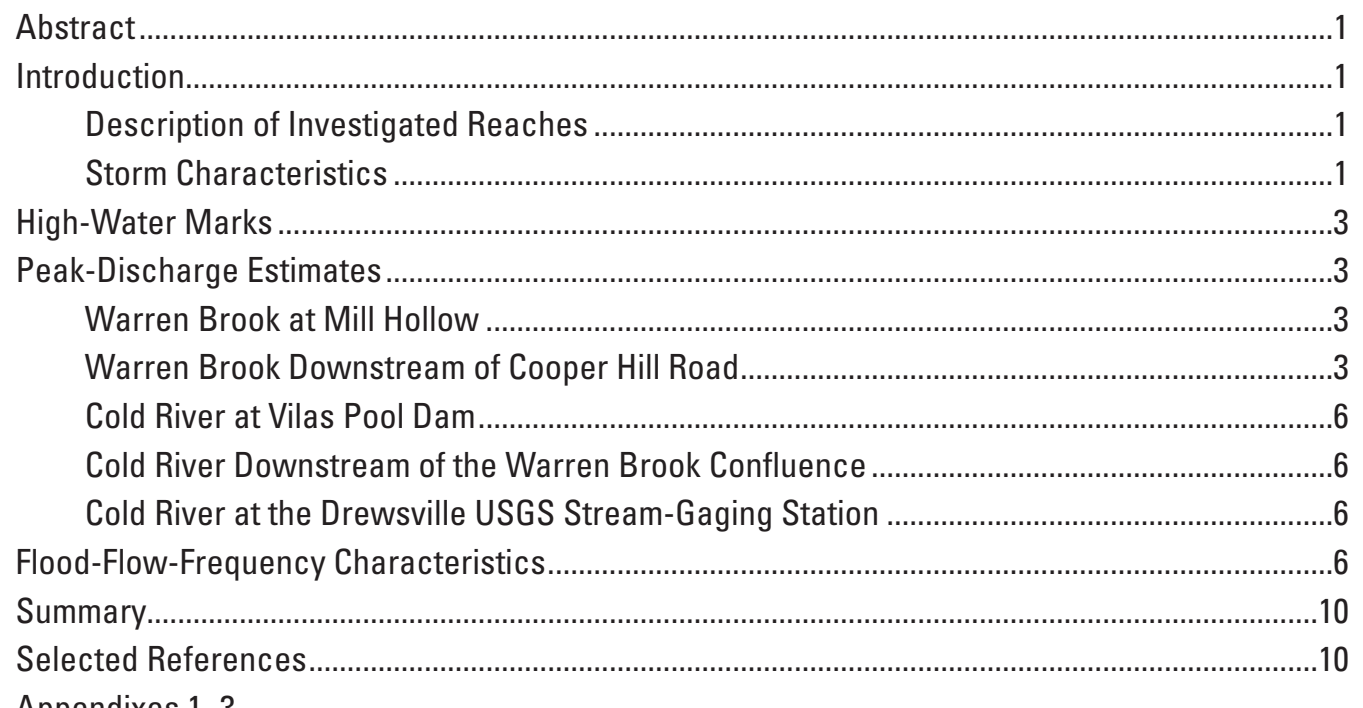

Appendixes 1-3.

1. Maps Showing Location of High-Water Marks Flagged in Walpole, Langdon, and Alstead, NH, Following the Flood of October 8 and 9, $2005 \ldots \ldots \ldots \ldots \ldots \ldots \ldots \ldots \ldots \ldots \ldots \ldots \ldots \ldots \ldots . . .22$

2. Profiles of the October 2005 Flood on Cold River and Warren Brook, Southwestern New Hampshire.....

3. Elevation Benchmarks Along Cold River and Warren Brook, New Hampshire ...............45

\section{Figures}

1-2. Maps showing-

1. Location of investigated reaches and the towns of Walpole, Langdon, and Alstead, $\mathrm{NH}$.

2. Locations where peak discharge and flood-flow frequency were estimated in Walpole, Langdon, and Alstead, NH .

3. Photograph showing view looking upstream at the Cooper Hill Road embankment failure October 2005 in Alstead, NH

4-5. Graphs showing-

4. Flood-flow frequency estimates for selected recurrence intervals at selected sites on Warren Brook, Alstead, NH....................................................................7

5. Flood-flow frequency estimates for selected recurrence intervals at selected sites on Cold River, Alstead, Langdon, and Walpole, NH. 


\section{Tables}

1. High-water elevations and locations of the October 2005 flood on Cold River in Walpole, Langdon, and Alstead, NH

2. High-water elevations of the October 2005 flood on Warren Brook in Alstead, NH .......17

3. Basin characteristics and flood-flow frequency estimates for selected recurrence intervals at selected sites on Warren Brook, Alstead, NH

4. Flood-flow frequency estimates for selected recurrence intervals at selected sites on Cold River, southwestern New Hampshire, 2005.

\section{Conversion Factors, Abbreviations, and Vertical Datum}

\begin{tabular}{|c|c|c|}
\hline Multiply & By & To obtain \\
\hline \multicolumn{3}{|c|}{ Length } \\
\hline inch (in.) & 25.40 & millimeter $(\mathrm{mm})$ \\
\hline foot (ft) & 0.3048 & meter $(\mathrm{m})$ \\
\hline mile (mi) & 1.609 & kilometer $(\mathrm{km})$ \\
\hline \multicolumn{3}{|c|}{ Area } \\
\hline square foot $\left(\mathrm{ft}^{2}\right)$ & 0.09290 & square meter $\left(\mathrm{m}^{2}\right)$ \\
\hline square mile $\left(\mathrm{mi}^{2}\right)$ & 2.589 & square kilometer $\left(\mathrm{km}^{2}\right)$ \\
\hline \multicolumn{3}{|c|}{ Volume } \\
\hline acre-foot (acre-ft) & 1,233 & cubic meter $\left(\mathrm{m}^{3}\right)$ \\
\hline \multicolumn{3}{|c|}{ Velocity and flow } \\
\hline foot per second (ft/s) & 0.3048 & meter per second $(\mathrm{m} / \mathrm{s})$ \\
\hline cubic foot per second $\left(\mathrm{ft}^{3} / \mathrm{s}\right)$ & 0.02832 & cubic meter per second $\left(\mathrm{m}^{3} / \mathrm{s}\right)$ \\
\hline $\begin{array}{l}\text { cubic foot per second per square } \\
\text { mile }\left[\left(\mathrm{ft}^{3} / \mathrm{s}\right) / \mathrm{mi}^{2}\right]\end{array}$ & 0.01094 & $\begin{array}{l}\text { cubic meter per second per square } \\
\text { kilometer }\left[\left(\mathrm{m}^{3} / \mathrm{s}\right) / \mathrm{km}^{2}\right]\end{array}$ \\
\hline \multicolumn{3}{|c|}{ Slope } \\
\hline foot per mile (ft/mi) & 0.1894 & meter per kilometer $(\mathrm{m} / \mathrm{km})$ \\
\hline
\end{tabular}

\section{Other Abbreviations}

CHWx-L Cold River high-water mark, left bank

CHWx-R Cold River high-water mark, right bank

FEMA Federal Emergency Management Agency

NOAA National Oceanic and Atmospheric Administration

NWS National Weather Service

USGS U.S. Geological Survey

WHWx-L Warren Brook high-water mark, left bank

WHWx-R Warren Brook high-water mark, right bank

In this report, the words "right" and "left" refer to directions that would be reported by an observer facing downstream.

NAVD 88: In this report, "NAVD 88" refers to the North American Vertical Datum of 1988. 


\title{
Flood of October 8 and 9, 2005, on Cold River in Walpole, Langdon, and Alstead and on Warren Brook in Alstead, New Hampshire
}

\author{
By Scott A. Olson
}

\begin{abstract}
Southwestern New Hampshire experienced damaging flooding on October 8 and 9, 2005. The flooding was the result of a storm producing at least 7 inches of rain in a 30 -hour period. The heavy, intense rainfall resulted in runoff and severe flooding, especially in regions of steep topography that are vulnerable to flash flooding. Some of the worst property damage was in the towns of Alstead, Langdon, and Walpole, New Hampshire along Cold River and Warren Brook. Warren Brook was severely flooded and had flows that exceeded a 100-year recurrence interval upstream of Cooper Hill Road. Downstream of Cooper Hill Road, the flooding was worsened as a result of a sudden release of impounded water, making the flood levels greater than what would be experienced from a 500-year recurrence-interval flood.

Along Cold River, upstream of its confluence with Warren Brook, flooding was at approximately a 100-year recurrence interval. Downstream of the confluence of Cold River and Warren Brook, the streamflows, which were swollen by the surge of water from Warren Brook, exceeded a 500year recurrence interval.
\end{abstract}

\section{Introduction}

Major flooding occurred in southwestern New Hampshire on October 8 and 9, 2005, as a result of torrential rainfall. The flooding resulted in seven deaths-four of which were in Alstead, NH. More than 100 buildings or homes were damaged or destroyed. Many miles of roads in the region were damaged and remained impassable for days, even weeks, following the flood.

On October 26, 2005, President George W. Bush declared a major disaster area in five counties in the State of New Hampshire as a result of widespread damage caused by the flooding. In response to this declaration, the U.S. Geological Survey (USGS), in cooperation with the Federal Emergency Management Agency, measured the high-water elevations, determined peak discharges as a result of the flooding, and estimated flood-flow frequency for selected watercourse areas affected by the flooding. The purpose of this report is to document the flood on Cold River in Walpole, Langdon, and Alstead, and on Warren Brook in Alstead, NH. Because of the severity of the flooding, the following communities and stream reaches were included in this report: (1) a 6.7-mi reach of Cold River from its mouth where it drains into the Connecticut River in Walpole, NH, to Vilas Pool Dam in Alstead, and (2) a 4.5-mi reach of Warren Brook from its mouth where it drains into Cold River to Warren Lake in Alstead.

\section{Description of Investigated Reaches}

Cold River (fig. 1) flows southwesterly through Alstead, Langdon, and Walpole along a relatively steep slope, averaging $45 \mathrm{ft} / \mathrm{mi}$, and drains into the Connecticut River at an elevation of about $230 \mathrm{ft}$. The headwaters of Cold River reach $1,900 \mathrm{ft}$ in elevation. Cold River is in the New England Upland physiographic region of southwestern New Hampshire. The drainage area of Cold River at its confluence with the Connecticut River is $102 \mathrm{mi}^{2}$.

Warren Brook (fig. 1) flows westerly through Alstead, draining into Cold River in steep topography. It is an upland stream, and is also in the New England Upland physiographic region. The elevation of the mouth of the Warren Brook is approximately $510 \mathrm{ft}$, and the headwaters extend to elevations above 1,500 ft. The average channel slope of the reach investigated is $150 \mathrm{ft} / \mathrm{mi}$. The drainage area of Warren Brook at its confluence with Cold River is $12.5 \mathrm{mi}^{2}$.

\section{Storm Characteristics}

The storm of October 8 and 9, 2005, produced at least 7 in. of precipitation (National Weather Service Forecast Office, 2005) in southwestern New Hampshire. Unverified accounts indicated as much as $12 \mathrm{in}$. of rain fell in a 30-hour period (Sarah Liebowitz, Concord Monitor, written commun., October 20, 2005). The precipitation station at Keene, $\mathrm{NH}$, operated by the National Oceanic and Atmospheric Administration, recorded 7.68 in. of rainfall from 


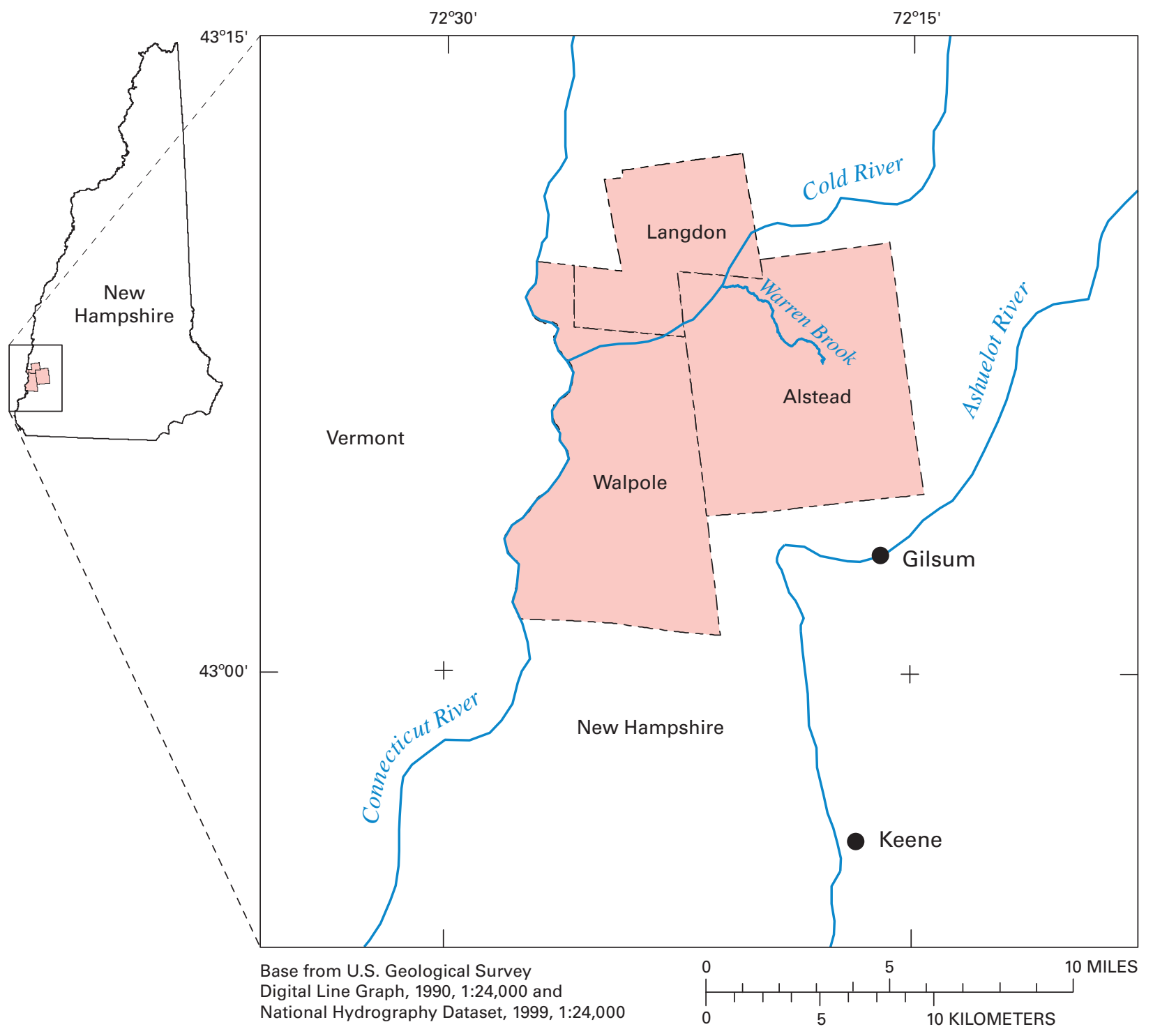

Figure 1. Location of investigated reaches and the towns of Walpole, Langdon, and Alstead, NH. 
October 8 through 9, 2005 (National Weather Service Forecast Office, 2005). Prior to the storm, hydrologic conditions in the area were predominately normal (U.S. Geological Survey, 2006). The heavy, intense rainfall resulted in runoff and severe flooding, especially in regions of steep topography that are vulnerable to flash flooding.

\section{High-Water Marks}

USGS personnel identified and flagged high-water marks along the investigated reaches of Cold River and Warren Brook following the flood. The high-water marks were tied into the North American Vertical Datum of 1988 (NAVD 88), using closed level-loop surveying techniques between October 31 and November 18, 2005. Latitude and longitude of the high-water marks were determined, using Global Positioning System instrumentation.

The elevation and location of the high-water marks are described in tables 1 and 2 (back of report) and the locations are plotted on USGS orthophotos in appendix 1. The highwater marks also are plotted in profile format for each investigated reach in appendix 2.

The high-water marks also are rated for accuracy. This rating is subjective and is based upon the type of high-water mark and the abundance of other confirming marks in the immediate vicinity (Benson and Dalrymple, 1967). The accuracy of the mark is defined as follows: A high-water mark having (1) an excellent rating is within $0.05 \mathrm{ft}$ of the actual water surface, (2) a good rating is within $0.1 \mathrm{ft}$, (3) a fair rating is within $0.2 \mathrm{ft}$, and (4) a poor rating may be greater than $0.2 \mathrm{ft}$ from the true peak water surface.

Elevation reference marks used to establish the elevations of the high-water marks are reported in appendix 3.

\section{Peak-Discharge Estimates}

In addition to obtaining high-water marks, USGS personnel surveyed cross sections in select locations so that the surveyed geometry data and the high-water-mark elevation data could be used together in hydraulic models to estimate the peak discharges. Peak-discharge estimates, using these indirect techniques, were made in four locations: Warren Brook at Mill Hollow, Cold River at Vilas Pool Dam, Cold River downstream of the Warren Brook confluence, and Cold River at the Drewsville USGS stream-gaging station (fig. 2). The peak-discharge estimates are discussed in upstream to downstream order.

Peak-discharge estimates of Warren Brook downstream of Cooper Hill Road (fig. 2) were made using a dam-breach model. This was used because of the nature of the failure of the Cooper Hill Road embankment that impounded flood waters.

\section{Warren Brook at Mill Hollow}

An indirect discharge measurement was made at the Route 123 crossing of Warren Brook at Mill Hollow. Although the Mill Hollow site has complex hydraulics, the site was selected because excellent high-water-mark elevations were available and the dam and culvert incurred minimal damage during the flooding. At the Mill Hollow site, the surveyed geometry of the dam, the Route 123 culvert, Route 123 roadway, and an approach cross section were input into the U.S. Army Corps of Engineers (2004) HEC-RAS program. Discharges were iteratively selected so that the resulting watersurface elevations output from HEC-RAS at the approach section matched the high-water marks surveyed upstream of the site. The resulting peak discharge for the October 2005 flood event was $820 \mathrm{ft}^{3} / \mathrm{s}$ for the $5.21-\mathrm{mi}^{2}$ drainage area.

\section{Warren Brook Downstream of Cooper Hill Road}

Peak-discharge estimates were determined immediately downstream of the Cooper Hill Road crossing of Warren Brook. During the flood, the Cooper Hill Road embankment impounded flood waters flowing down Warren Brook. Using the National Elevation Dataset (U.S. Geological Survey, 2001), the impoundment was computed to be 421 acre-ft of water. When the nearly $30-\mathrm{ft}$ tall road embankment was overtopped, it breached, sending the entire impounded pool of floodwaters rushing downstream.

Because of the apparent similarities of the impoundment failure to an earthen dam failure, the National Weather Service's Simplified Dam-Break (SMPDBK) Flood Forecasting Model (Wetmore and Fread, 1991) was used to estimate the peak discharges downstream of the breached road embankment. The geometry of the breached road embankment was surveyed and used as input along with the impoundment volume. Additional cross sections downstream of the Cooper Hill Road crossing along Warren Brook to its mouth were estimated from the USGS 1:24,000 topographic map (U.S. Geological Survey, 1998a) and also used as input to the model. The additional cross sections allowed the SMPDBK model to route the peak discharge down Warren Brook to its mouth where it drains into Cold River.

The discharges computed by the SMPDBK model were sensitive to the amount of time that the road embankment was given to completely breach. The breach occurred in about a 20- to 30-minute timeframe (David Crosby, town of Alstead Director of Public Works, oral commun., December 19, 2005). Thus, a breach time of 25 minutes was used in the model. The results from SMPDBK indicate a peak discharge immediately downstream of Cooper Hill Road of $24,900 \mathrm{ft}^{3} / \mathrm{s}$ and a peak discharge of $20,100 \mathrm{ft}^{3} / \mathrm{s}$ at the confluence with Cold River. Decreasing the time to 20 minutes increased peak discharges by approximately 7 percent; increasing the breach time to 30 minutes decreased peak discharges by about 3 percent. 


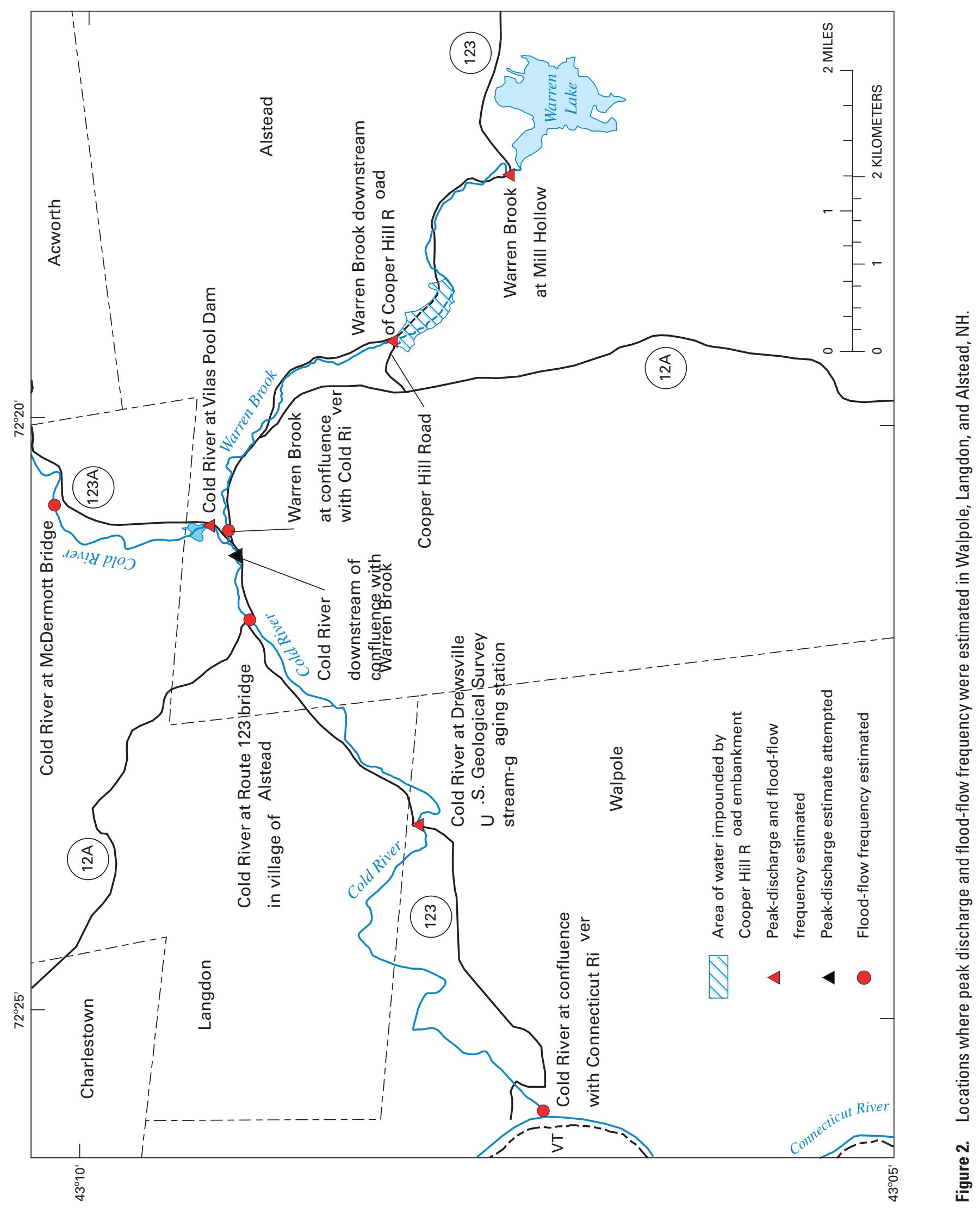




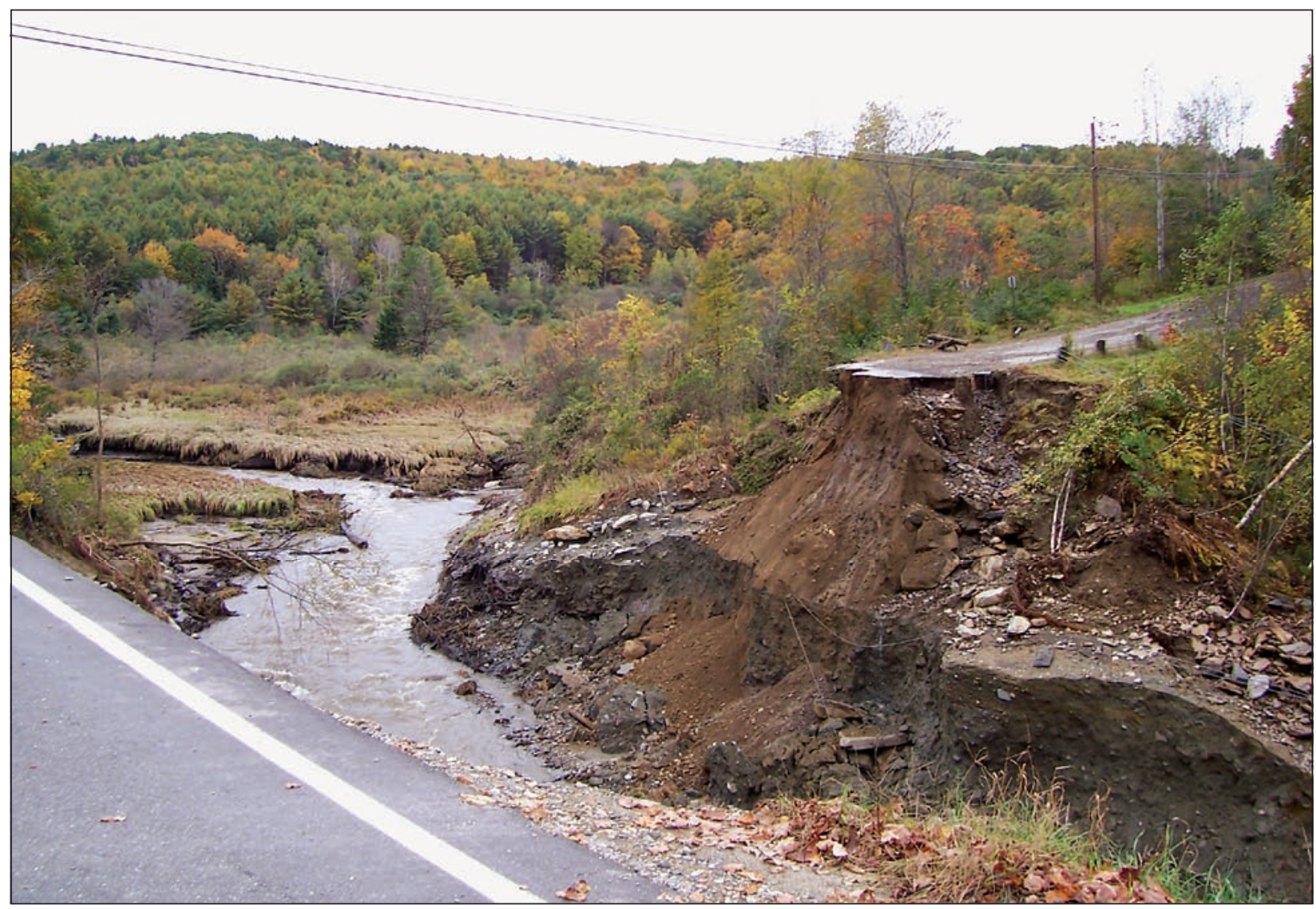

Photograph courtesy of Reggie Clark, Alstead, NH

Figure 3. View looking upstream at the Cooper Hill Road embankment failure October 2005 in Alstead, NH. 


\section{Cold River at Vilas Pool Dam}

An indirect discharge measurement was made for Cold River at Vilas Pool Dam. The site is not considered ideal for an indirect discharge measurement as described by Hulsing (1967) because a large percentage of the flow is diverted over Route $123 \mathrm{~A}$ adjacent to the dam. The flow over Route 123A and Vilas Pool Dam were modeled as a broad-crested weir. The geometry of the dam, the Route 123A overflow section, and an approach cross section were surveyed and input into the U.S. Army Corps of Engineers (2004) HECRAS program. Discharges were iteratively selected so that the resulting water-surface elevations output from HEC-RAS at the approach section matched the high-water-mark elevations at the approach section at Vilas Pool Dam. The resulting peak discharge was $6,370 \mathrm{ft}^{3} / \mathrm{s}$ for the $61.3-\mathrm{mi}^{2}$ drainage area.

\section{Cold River Downstream of the Warren Brook Confluence}

An indirect discharge measurement was attempted on Cold River downstream of the Warren Brook confluence (fig. 2). However, an acceptable indirect discharge could not be generated because of complex hydraulics.

\section{Cold River at the Drewsville USGS Stream- Gaging Station}

An indirect discharge measurement was made for the discontinued USGS stream-gaging station, Cold River at Drewsville, NH, station number 01155000. The streamgage is located about $60 \mathrm{ft}$ upstream of the Route 123 crossing of
Cold River in Drewsville and has a drainage area of $82.7 \mathrm{mi}^{2}$. Continuous record was collected at the station from 1940 to 1978. During the period of record, the maximum recorded discharge was $6,710 \mathrm{ft}^{3} / \mathrm{s}$ on December 21, 1973 (U.S. Geological Survey, 1978). The corresponding maximum stage was $12.30 \mathrm{ft}$, which when converted to NAVD 88 is $390.58 \mathrm{ft}$. The October 9, 2005, peak stage was $401.98 \mathrm{ft}$, or $11.40 \mathrm{ft}$ higher than the peak stage of December 21, 1973.

The reach used for the indirect discharge measurement was a straight section of river with a broad flood plain left of the channel starting at about 2,500 ft upstream of the station. The reach met all the criteria for an indirect discharge measurement using the Slope-Area method as described in Dalrymple and Benson (1967). Three cross sections were surveyed and used as input into the Slope-Area Computation program (Fulford, 1994) along with the corresponding highwater elevations. The resulting peak discharge was estimated to be $21,800 \mathrm{ft}^{3} / \mathrm{s}$. The wide flood plains downstream of the Village of Alstead and upstream of the reach used for the indirect measurement may have attenuated some of the flood wave from the breached Cooper Hill Road embankment on Warren Brook.

\section{Flood-Flow-Frequency Characteristics}

The flood-flow-frequency estimates are discussed in upstream to downstream order. Flood-flow frequency estimates for Warren Brook were estimated using regression equations developed by LeBlanc (1978) (table 3, fig. 4).

Basin characteristics used as input to the regression equations include drainage area, mean channel slope, and the 2-year,

Table 3. Basin characteristics and flood-flow frequency estimates for selected recurrence intervals at selected sites on Warren Brook, Alstead, NH.

[Location of sites shown in figure 2. Flood-flow frequency estimates plotted against drainage area are in figure 4. $\mathrm{ft}^{3} / \mathrm{s}$, cubic feet per second; ft/mi, feet per mile; hr, hour; in., inches; $\mathrm{mi}^{2}$, square mile; yr, year]

\begin{tabular}{|c|c|c|c|c|c|c|c|}
\hline \multirow[t]{2}{*}{ Warren Brook site } & \multirow{2}{*}{$\begin{array}{l}\text { Drainage } \\
\text { area, } \\
\text { mi }^{2}\end{array}$} & \multirow{2}{*}{$\begin{array}{l}\text { Channel } \\
\text { slope, } \\
\mathrm{ft} / \mathrm{mi}\end{array}$} & \multirow{2}{*}{$\begin{array}{l}\text { 2-yr, 24-hr } \\
\text { rainfall, } \\
\text { in. }\end{array}$} & \multicolumn{4}{|c|}{$\begin{array}{l}\text { Flood-flow frequency estimates for selected } \\
\text { recurrence intervals, } \\
\qquad \mathrm{ft}^{3} / \mathrm{s}\end{array}$} \\
\hline & & & & $10 \mathrm{yr}$ & $50 \mathrm{yr}$ & $100 \mathrm{yr}$ & $500 \mathrm{yr}$ \\
\hline Mill Hollow & 5.21 & 101 & 2.7 & 289 & 508 & 615 & 958 \\
\hline Downstream of Cooper Hill Road & 9.24 & 147 & 2.7 & 629 & 1,140 & 1,380 & 2,190 \\
\hline
\end{tabular}




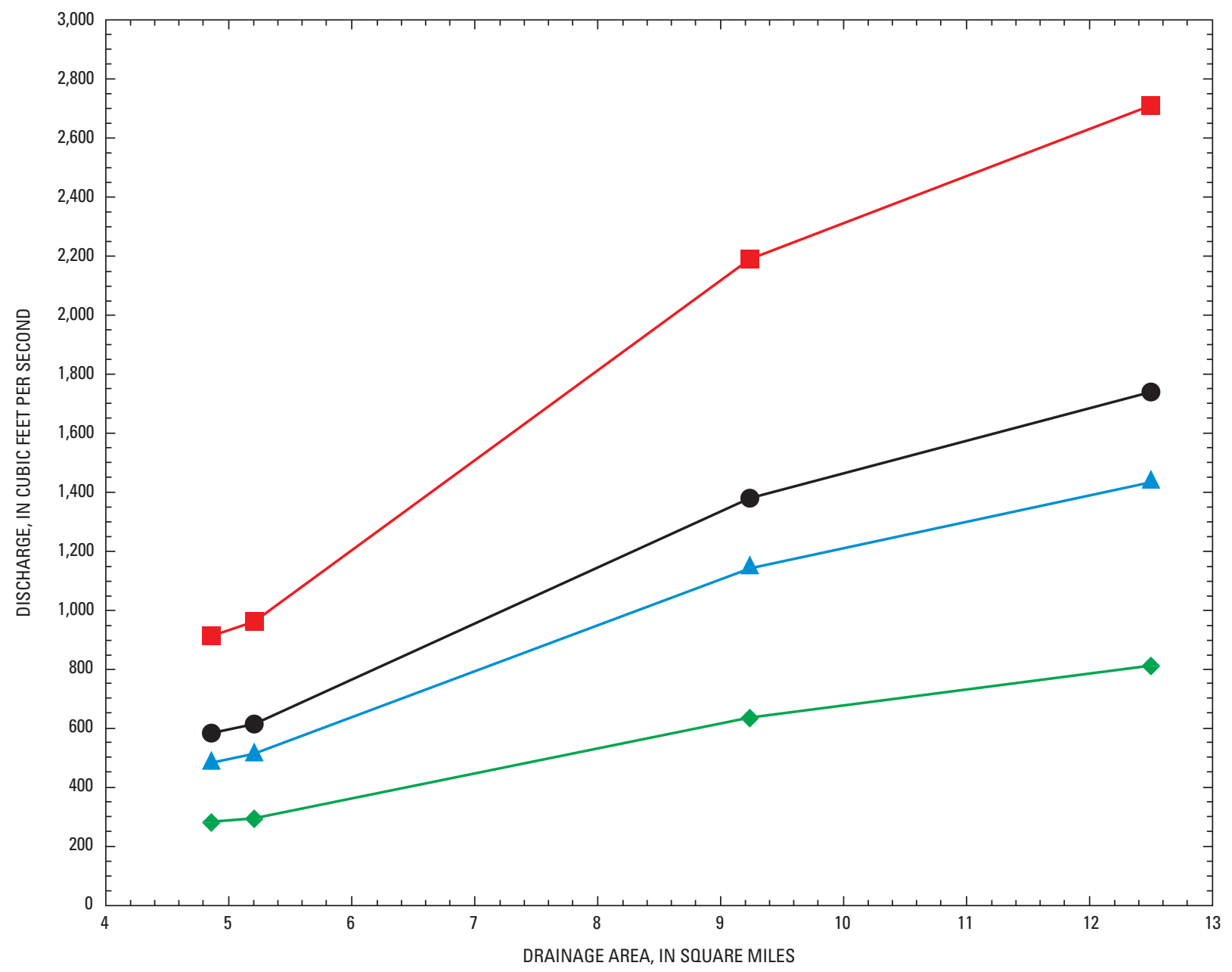

\section{EXPLANATION}

Flood-flow frequency estimates for selected recurrence intervals

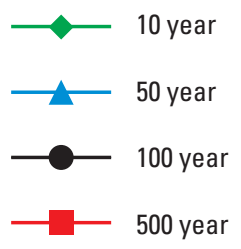

Figure 4. Flood-flow frequency estimates for selected recurrence intervals at selected sites on Warren Brook, Alstead, NH. Location and information for selected sites are shown in figure 2 and table 3 (outlet of Lake Warren is represented by the first data points but values are not shown on table 3). 
24-hour rainfall for the basin. Drainage area and mean channel slope were determined using a Geographic Information System, electronic copies of USGS 1:24,000 topographic maps (U.S. Geological Survey, 1998a-d) and the National Elevation Dataset (U.S. Geological Survey, 2001). The 2-year, 24-hour rainfall was determined from a rainfall-frequency atlas (Hershfield, 1961). These data sources for the basin characteristics are nearly identical to the data sources used to derive the LeBlanc regression equations.

Flood discharges at the 10-, 50-, 100-, and 500-year recurrence intervals for Cold River at Drewsville were determined using a log-Pearson Type III analysis (U.S. Interagency Advisory Committee on Water Data, 1982). Peak-flow data from Cold River at Drewsville, NH, stream-gaging station were used for computing the frequency curve. The October 2005 peak was adjusted to a "natural" peak-without the effect of the embankment breach on Warren Brook.

Several approaches were investigated to determine a natural peak at Cold River station. The first approach involved applying the peak runoff rate in cubic feet per second per square mile for this flood from the nearby Ashuelot River (fig. 1), as a way to estimate the natural peak on Cold River. The peak discharge of the Ashuelot River at the discontinued Gilsum, NH, USGS stream-gaging station was determined to be $10,200 \mathrm{ft}^{3} / \mathrm{s}$ using the Slope-Area technique (Dalrymple and Benson, 1967). The drainage area at the Ashuelot River at Gilsum, $\mathrm{NH}$, station is $71.1 \mathrm{mi}^{2}$, resulting in a $143-\mathrm{ft}^{3} / \mathrm{mi}^{2}$ runoff rate for the peak discharge. The drainage area of Cold River at Vilas Pool Dam $\left(61.3 \mathrm{mi}^{2}\right)$ had a peak runoff rate, however, of $104 \mathrm{ft}^{3} / \mathrm{mi}^{2}$; applying the runoff rate of the Ashuelot River to Cold River likely would have resulted in an overestimate of the natural peak flow.

Another approach was to apply the $104-\mathrm{ft}^{3} / \mathrm{mi}^{2}$ runoff rate from Vilas Pool Dam to Cold River at the Drewsville site. The runoff rate at Warren Brook at Mill Hollow was much greater at $158 \mathrm{ft}^{3} / \mathrm{mi}^{2}$; however, applying the lower Vilas Pool Dam runoff rate may result in an underestimate of the peak flow.

It was determined that the best approach to determine a natural peak was to use a drainage-area-weighted runoff rate using the Warren Brook runoff rate and Cold River at Vilas Pool Dam runoff rate. This weighted approach resulted in a runoff rate of $113 \mathrm{ft}^{3} / \mathrm{mi}^{2}$. Applying this runoff rate to Cold River at Drewsville stream-gaging station drainage area of $82.7 \mathrm{mi}^{2}$ resulted in a rate of $9,360 \mathrm{ft}^{3} / \mathrm{s}$. This rate was the natural peak-discharge estimate that was included in the log-Pearson Type III analysis. The results of the frequency analysis are shown in table 4 and figure 5 . The frequency curve then was adjusted to locations upstream and downstream of the station by applying a drainage-area ratio. For example, $\mathrm{Q}=\mathrm{Qgage}(\mathrm{A} /$ Agage $)$, where Qgage and Agage are the discharge and drainage area of the station and $\mathrm{Q}$ and $\mathrm{A}$ are the discharge and drainage area of the site of interest, respectively.

Table 4. Flood-flow frequency estimates for selected recurrence intervals at selected sites on Cold River, southwestern New Hampshire, 2005.

[Location of sites shown in figure 2. Flood-flow frequency estimates plotted against drainage area are shown in figure 5 . $\mathrm{ft}^{3} / \mathrm{s}$, cubic feet per second; mi ${ }^{2}$, square mile; yr, year]

\begin{tabular}{|c|c|c|c|c|c|}
\hline \multirow{2}{*}{ Cold River site } & \multirow{2}{*}{$\begin{array}{l}\text { Drainage area, } \\
\mathrm{mi}^{2}\end{array}$} & \multicolumn{4}{|c|}{$\begin{array}{l}\text { Flood-flow frequency estimates for selected recurrence intervals, } \\
\qquad \mathrm{ft}^{3} / \mathrm{s}\end{array}$} \\
\hline & & $10 \mathrm{yr}$ & $50 \mathrm{yr}$ & $100 \mathrm{yr}$ & $500 \mathrm{yr}$ \\
\hline Vilas Pool Dam, Alstead, NH & 61.3 & 3,030 & 5,080 & 6,190 & 9,410 \\
\hline $\begin{array}{l}\text { Cold River at Drewsville, NH, USGS stream- } \\
\text { gaging station }\end{array}$ & 82.7 & 4,090 & 6,860 & 8,350 & 12,700 \\
\hline Confluence with the Connecticut River & 102 & 5,040 & 8,460 & 10,300 & 15,700 \\
\hline
\end{tabular}




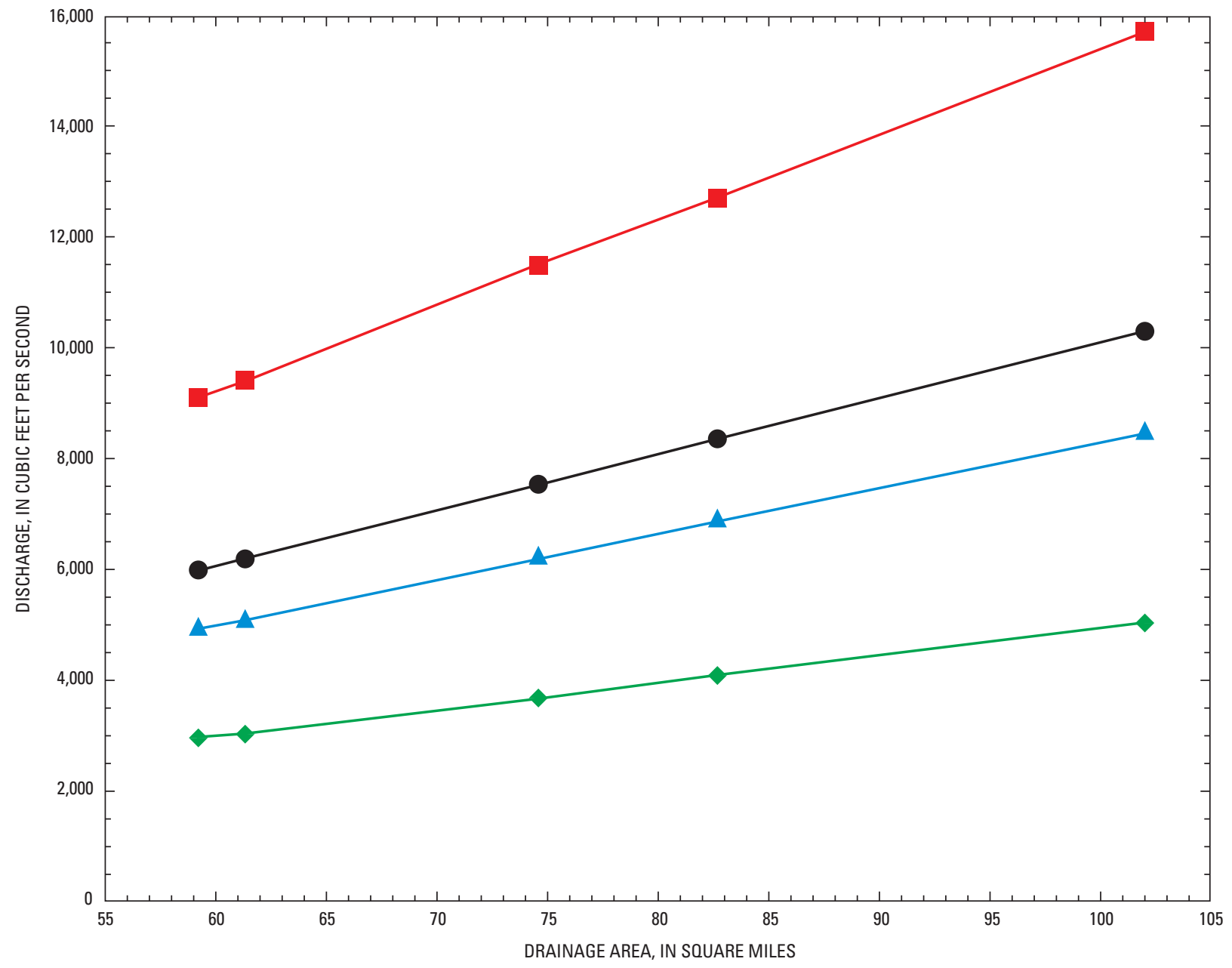

\section{EXPLANATION}

Flood-flow frequency estimates for selected recurrence intervals

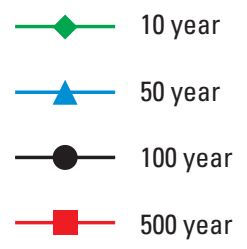

Figure 5. Flood-flow frequency estimates for selected recurrence intervals at selected sites on Cold River, Alstead, Langdon, and Walpole, NH. Location and information for selected sites are shown in figure 2 and table 4. 
Summary of flood-flow frequency estimates and peak-discharge estimates of the October 2005 flood at selected locations in Walpole, Langdon, and Alstead, NH.

[ft³ $/ \mathrm{s}$, cubic feet per second; $\mathrm{mi}^{2}$, square miles; yr, year; --, no data; >, greater than; , approximately]

\begin{tabular}{|c|c|c|c|c|c|c|c|}
\hline \multirow{2}{*}{ Location } & \multirow{2}{*}{$\begin{array}{l}\text { Drainage } \\
\text { area, } \\
\text { mi }^{2}\end{array}$} & \multicolumn{4}{|c|}{$\begin{array}{l}\text { Flood-flow frequency estimates for selected } \\
\text { recurrence intervals, } \\
\mathrm{ft}^{3} / \mathrm{s}\end{array}$} & \multirow{2}{*}{$\begin{array}{c}\text { Peak } \\
\text { discharge, } \\
\text { October 2005, } \\
\mathrm{ft}^{3} / \mathrm{s}\end{array}$} & \multirow{2}{*}{$\begin{array}{c}\text { Recurrence } \\
\text { interval } \\
\text { of peak } \\
\text { discharge }\end{array}$} \\
\hline & & $10 \mathrm{yr}$ & $50 \mathrm{yr}$ & $100 \mathrm{yr}$ & $500 \mathrm{yr}$ & & \\
\hline $\begin{array}{l}\text { Downstream of } \\
\text { Cooper Hill Road, Alstead, NH }\end{array}$ & 9.24 & 629 & 1,140 & 1,380 & 2,190 & 24,900 & $>500$-year \\
\hline At confluence with Cold River, Alstead, NH & 12.5 & 805 & 1,430 & 1,740 & 2,710 & 20,100 & $>500$-year \\
\hline \multicolumn{8}{|c|}{ Cold River } \\
\hline $\begin{array}{l}\text { At Cold River at Drewsville, NH, USGS stream- } \\
\text { gaging station }\end{array}$ & 82.7 & 4,090 & 6,860 & 8,350 & 12,700 & 21,800 & $>500$-year \\
\hline $\begin{array}{l}\text { At confluence with Connecticut River, } \\
\text { Walpole, } \mathrm{NH}\end{array}$ & 102 & 5,040 & 8,460 & 10,300 & 15,700 & -- & -- \\
\hline
\end{tabular}

\section{Summary}

The U.S. Geological Survey, in cooperation with the Federal Emergency Management Agency, surveyed highwater marks along the flooded reaches of Cold River in Alstead, Langdon, and Walpole, NH, and Warren Brook in Alstead, NH, to document the flood of October 8 and 9, 2005. Discharge estimates also were made in selected locations along these reaches. The peak discharges in Warren Brook downstream of Cooper Hill Road and in Cold River downstream of the confluence of Cold River and Warren Brook are attributed to the failure of a road embankment that released 421 acre-feet of impounded water in a 20- to 30-minute timeframe. New flow-frequency curves were determined for the investigated reaches as well.

\section{Selected References}

Benson, M.A., and Dalrymple, Tate, 1967, General field and office procedures for indirect discharge measurements: U.S. Geological Survey Techniques of Water-Resources Investigations, book 3, chap. A1, 30 .

Bodhaine, G.L., 1968, Measurement of peak discharge at culverts by indirect methods: U.S. Geological Survey Techniques of Water-Resource Investigations, book 3, chap. A3, 60 p.

Dalrymple, Tate, and Benson, M.A., 1967, Measurement of peak discharge by the slope-area method: U.S. Geological Survey Techniques of Water-Resource Investigations, book 3, chap. A2, 12 p. 
Federal Emergency Management Agency, 2000, Flood insurance study, Town of Walpole, Cheshire County, New Hampshire: Washington, DC, p. 16.

Fulford, J.M., 1994, User's guide to SAC, A computer program for computing discharge by slope-area method: U.S. Geological Survey Open-File Report 94-360, 31 p.

Hershfield, D.M., 1961, Rainfall frequency atlas of the United States for durations from 30 minutes to 24 hours and return periods from 1 to 100 years: U.S. Department of Commerce Weather Bureau Technical Paper No. 40, 61 p.

Hulsing, Harry, 1967, Measurement of peak discharge at dams by indirect methods: U.S. Geological Survey Techniques of Water-Resource Investigations, book 3, chap. A5, 29 p.

LeBlanc, D.R., 1978, Progress report on hydrologic investigations of small drainage areas in New Hampshire-Preliminary relations for estimating peak discharges on rural, unregulated streams: U.S. Geological Survey WaterResources Investigations 78-47, 9 p.

National Weather Service Forecast Office, 2005, Daily climate data, accessed December 20, 2005, at http://www.erh.noaa.gov/er/box/dailystns.shtml.

U.S. Army Corps of Engineers, 2004, HEC-RAS River Analysis System Version 3.1.2: Hydrologic Engineering Center, accessed October 26, 2004, at http://www.hec.usace.army.mil/.

U.S. Geological Survey, 1978, Water resources data for New Hampshire and Vermont, water year 1978: U.S. Geological Survey Water-Data Report NH-VT-78-1, 188 p.
U.S. Geological Survey, 1998a, Alstead, New Hampshire 7.5-minute series quadrangle map: U.S. Geological Survey Topographic Maps, scale 1:24,000.

U.S. Geological Survey, 1998b, Bellows Falls, VermontNew Hampshire 7.5-minute series quadrangle map: U.S. Geological Survey Topographic Maps, scale 1:24,000.

U.S. Geological Survey, 1998c, Gilsum, New Hampshire 7.5-minute series quadrangle map: U.S. Geological Survey Topographic Maps, scale 1:24,000.

U.S. Geological Survey, 1998d, Walpole, New HampshireVermont 7.5-minute series quadrangle map: U.S. Geological Survey Topographic Maps, scale 1:24,000.

U.S. Geological Survey, 2001, National elevation dataset, accessed May 5, 2004, at http://edcnts12.cr.usgs.gov/ned/.

U.S. Geological Survey, 2006, Water resources conditions in New Hampshire and Vermont September 2005, accessed April 21, 2006, at http://nh.water.usgs.gov/WaterData/2005/ sep05.htm.

U.S. Interagency Advisory Committee on Water Data, 1982, Guidelines for determining flood flow frequency, Bulletin 17-B of the Hydrology Subcommittee: Reston, VA, U.S. Geological Survey, Office of Water Data Coordination, $183 \mathrm{p}$.

Wetmore, J.N., and Fread, D.L., 1991, The National Weather Service simplified dam-break flood forecasting model (CD Rom with documentation): National Weather Service Hydrologic Research Laboratory, National Technical Information Service order no. PB 2003-500005, accessed December 2005, at http://www.NTIS.gov. 



\section{Tables 1-2}




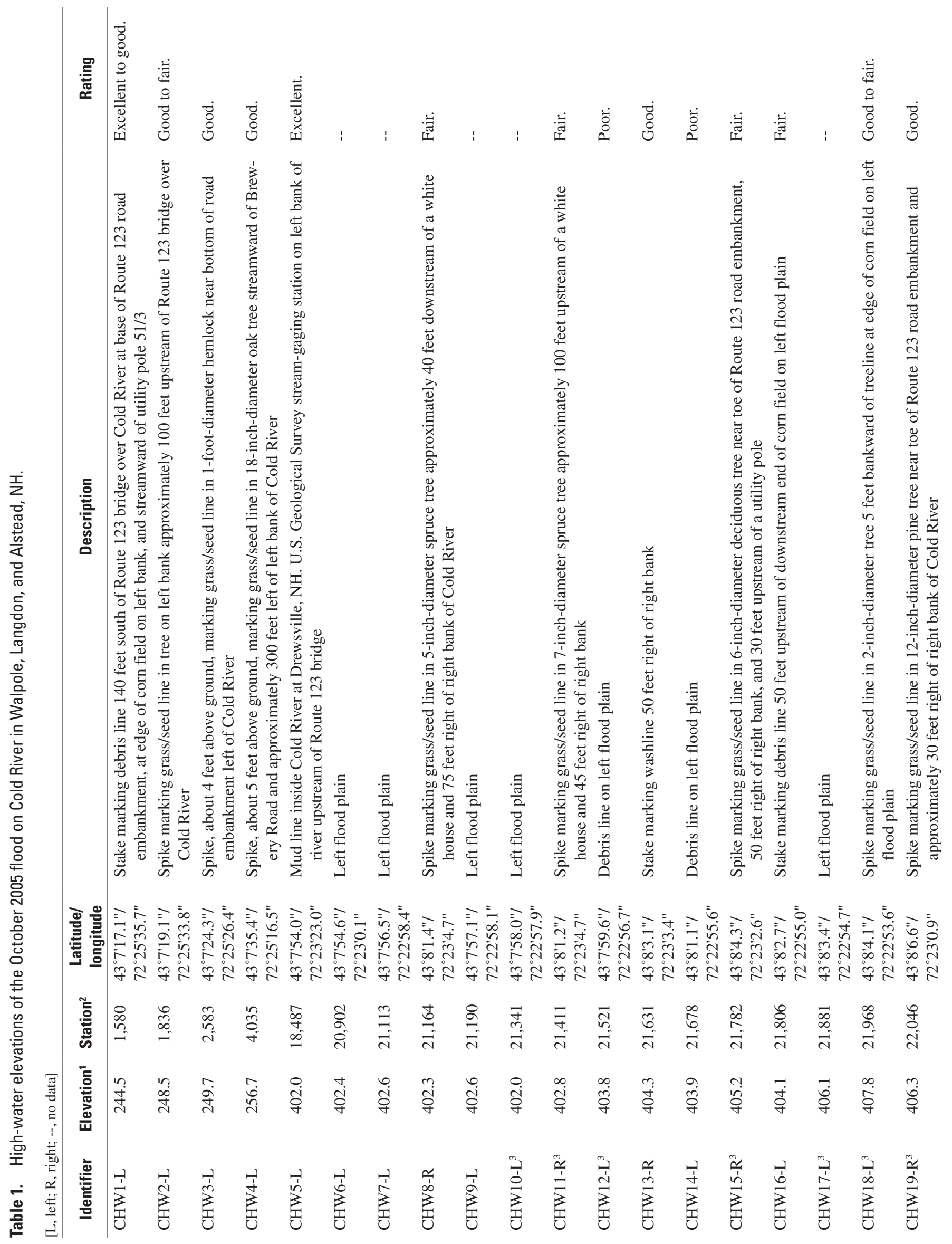




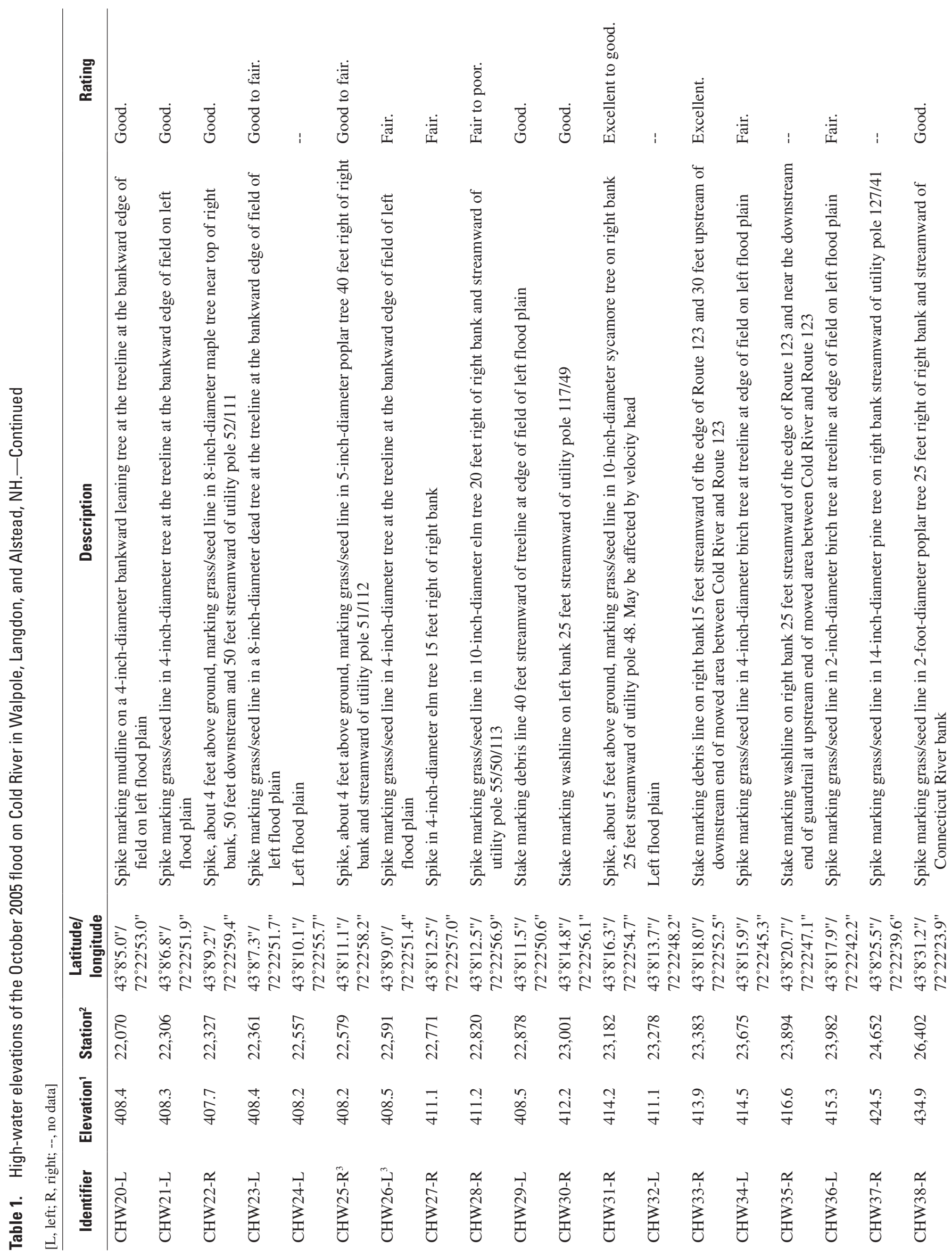




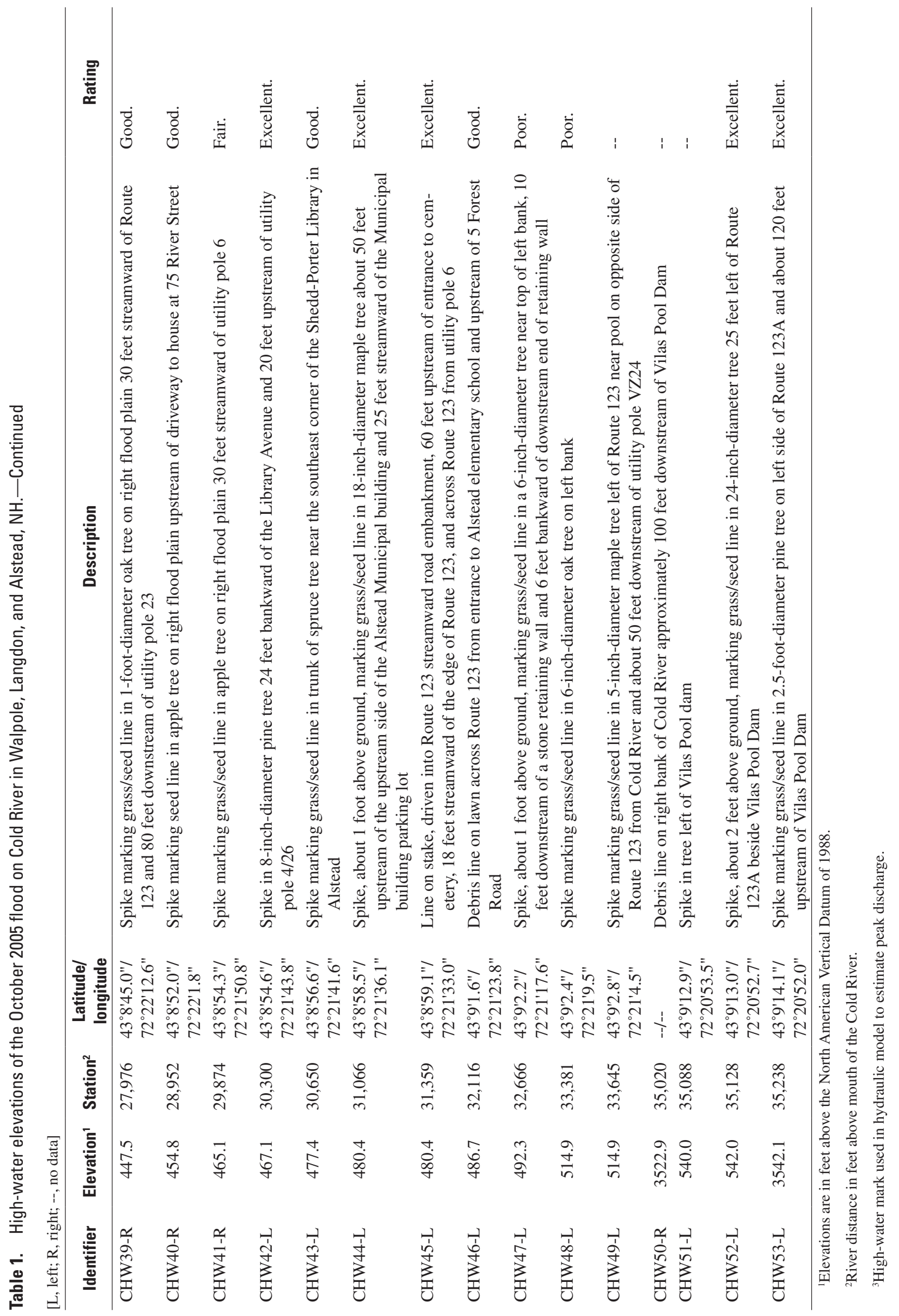




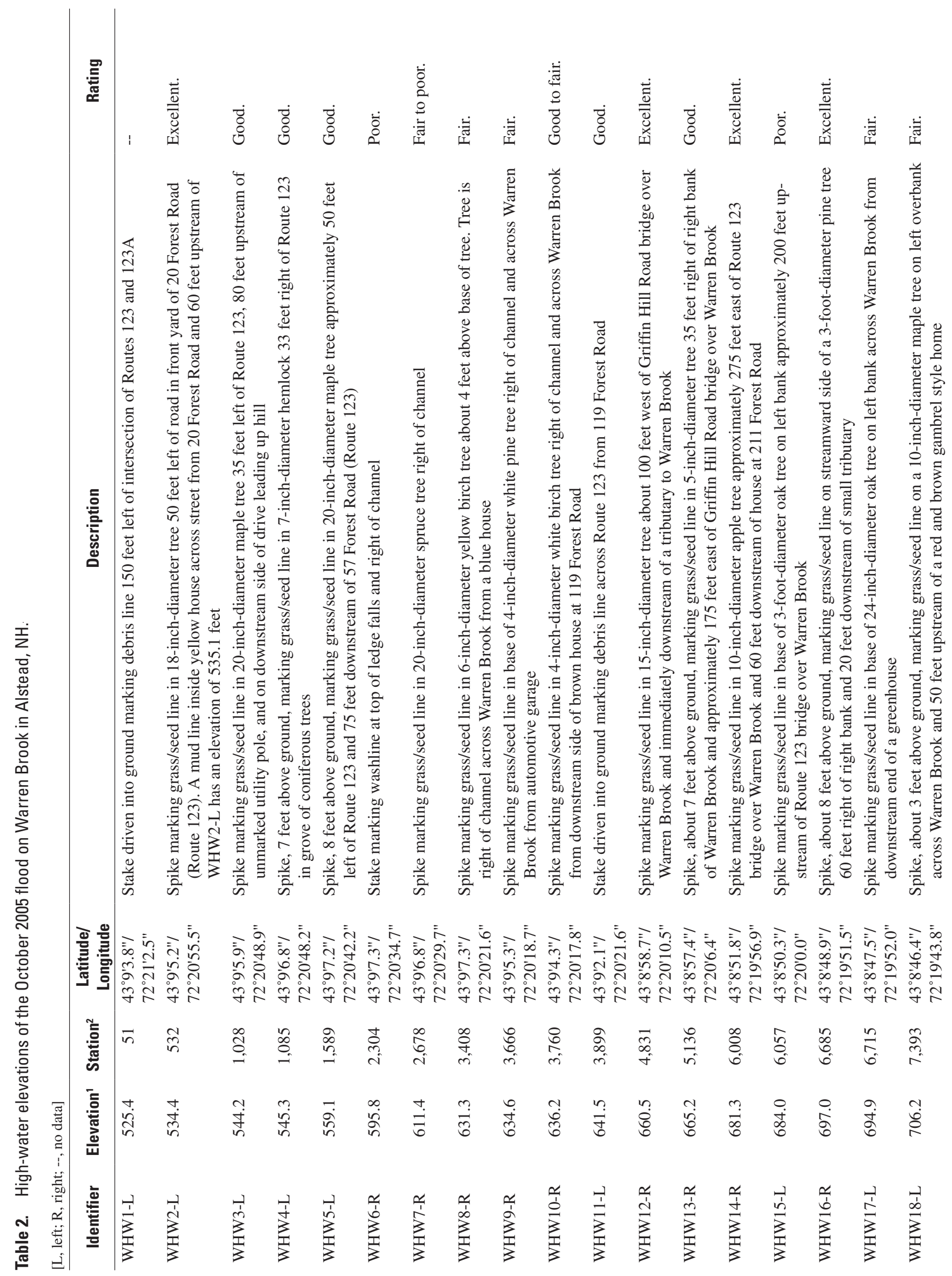




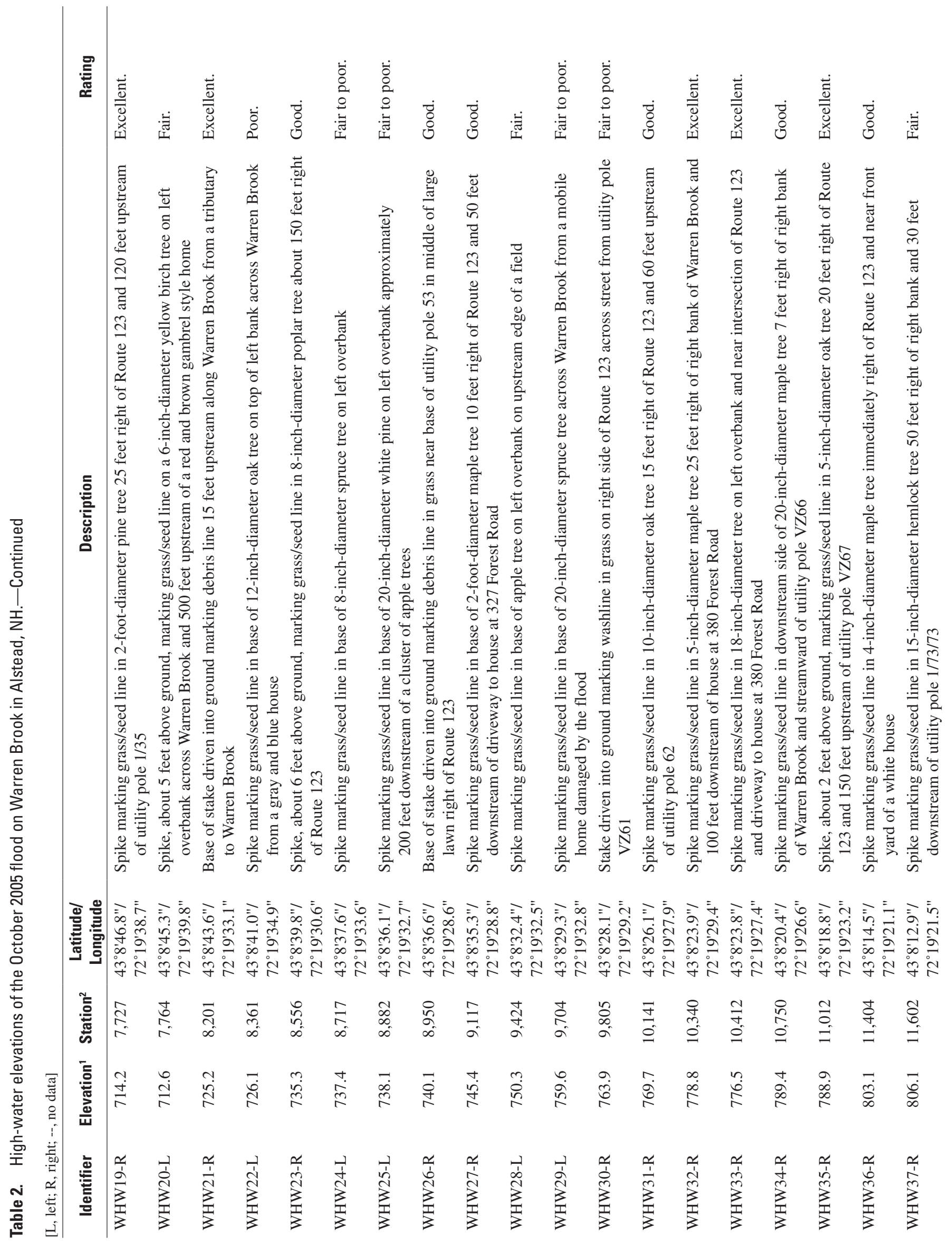




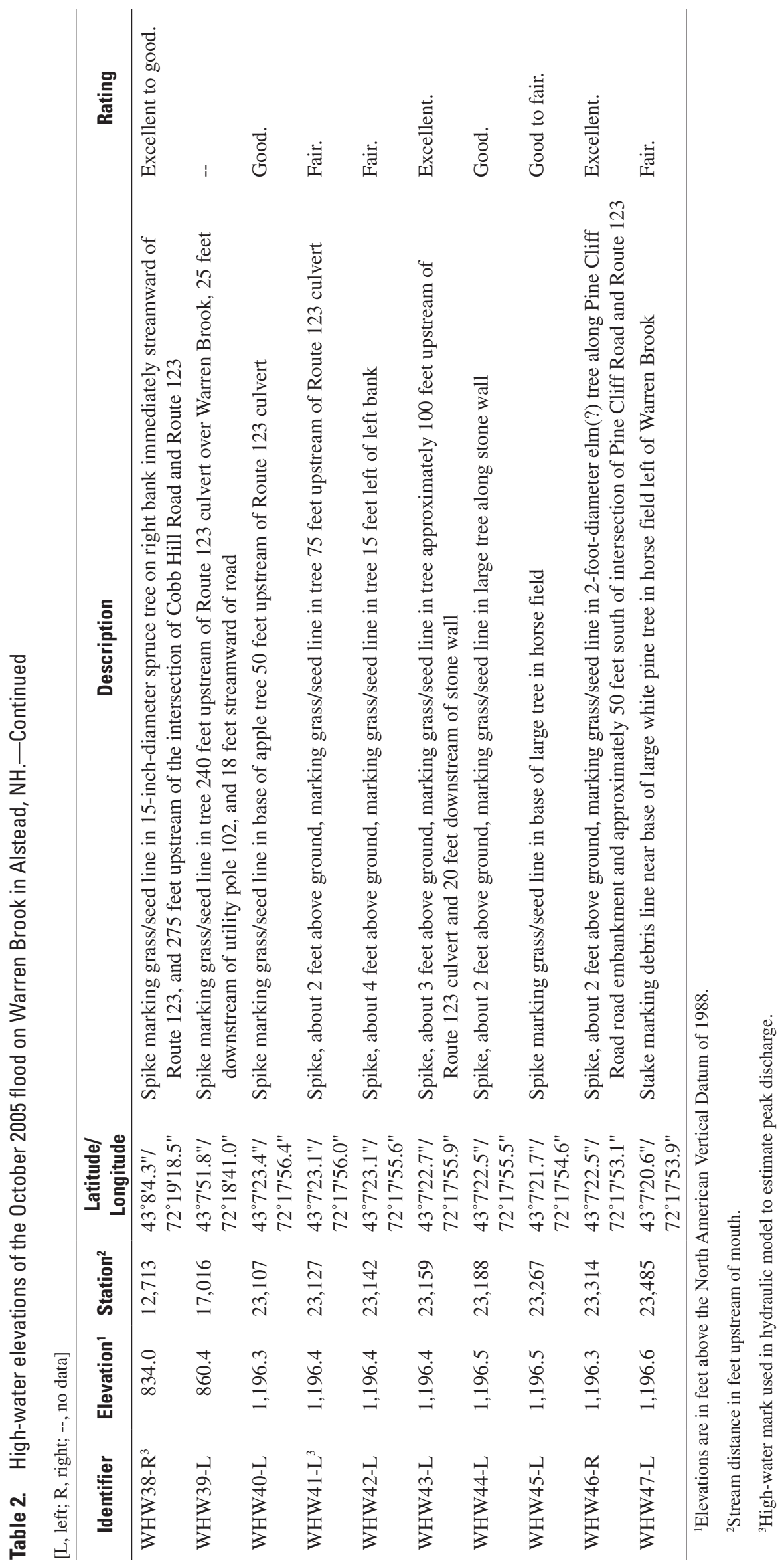



Appendixes 1-3 


\section{Appendix 1: Maps Showing Location of High-Water Marks Flagged in Walpole, Langdon, and Alstead, NH, Following the Flood of October 8 and 9, 2005}

Figures in appendix 1 begin at the mouth of Cold River, proceed upstream along Cold River to confluence of Cold River and Warren Brook, and then proceed upstream along Warren Brook to Warren Lake. 


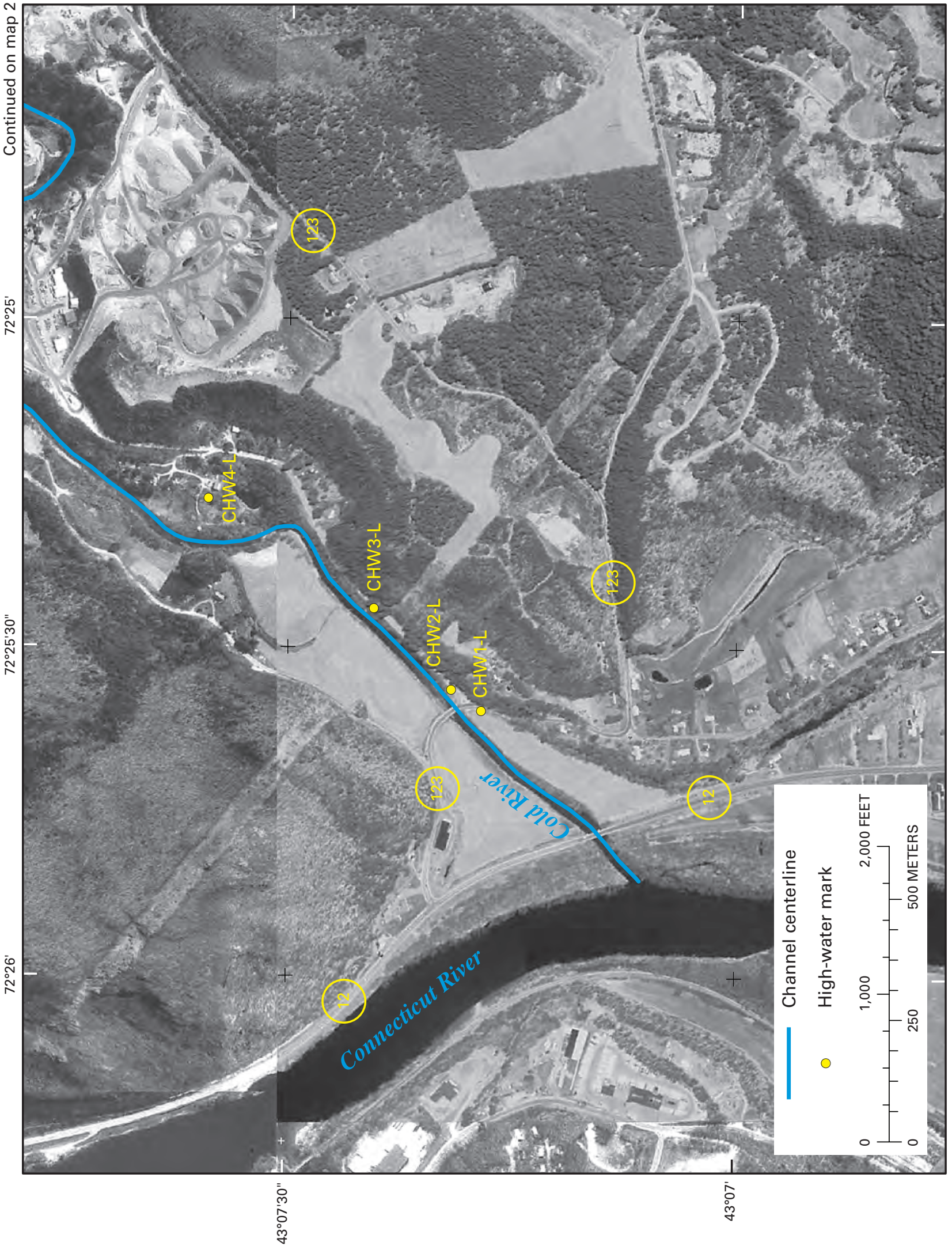

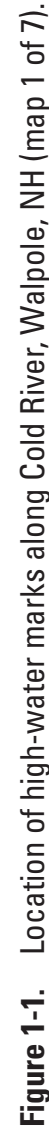




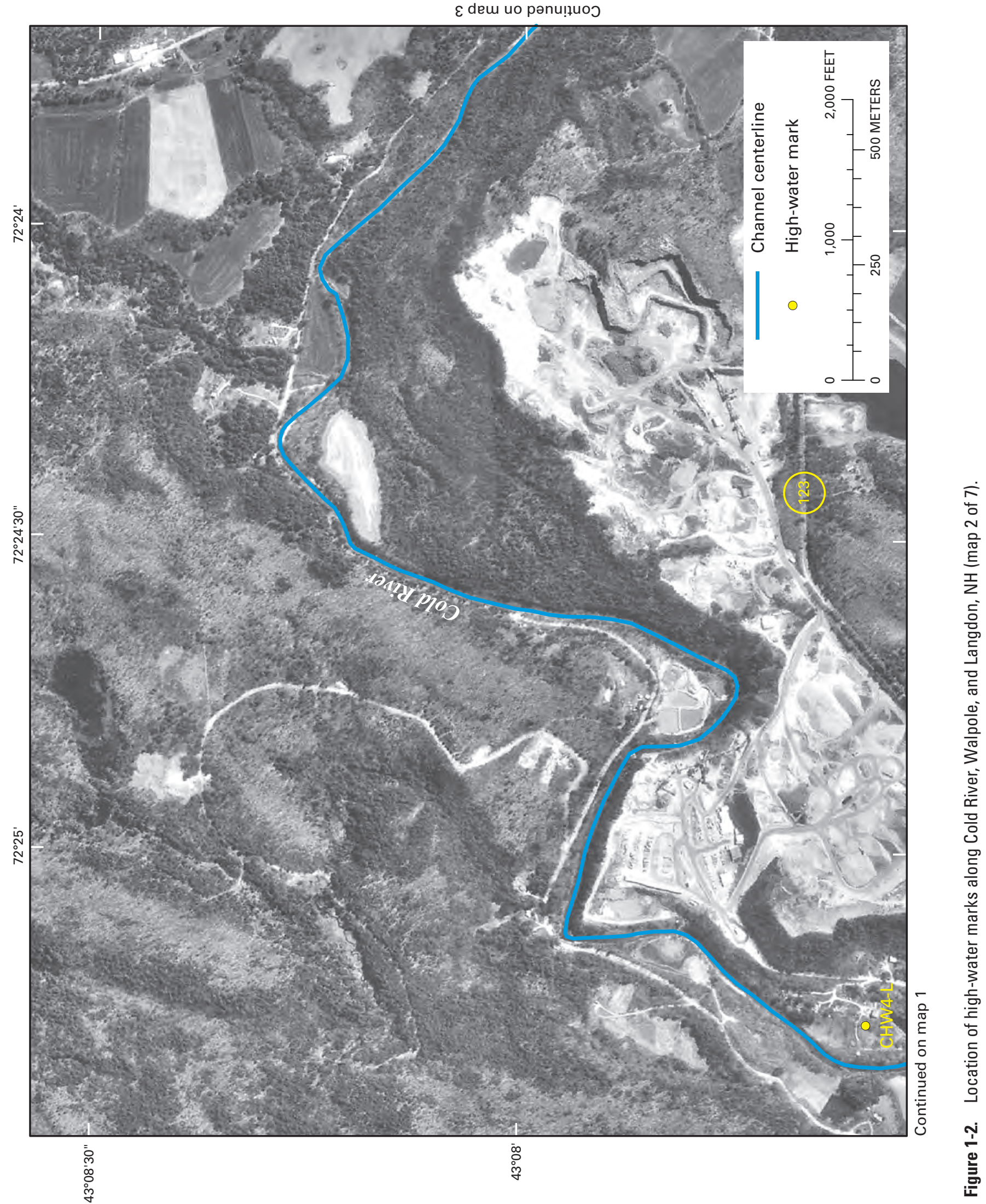




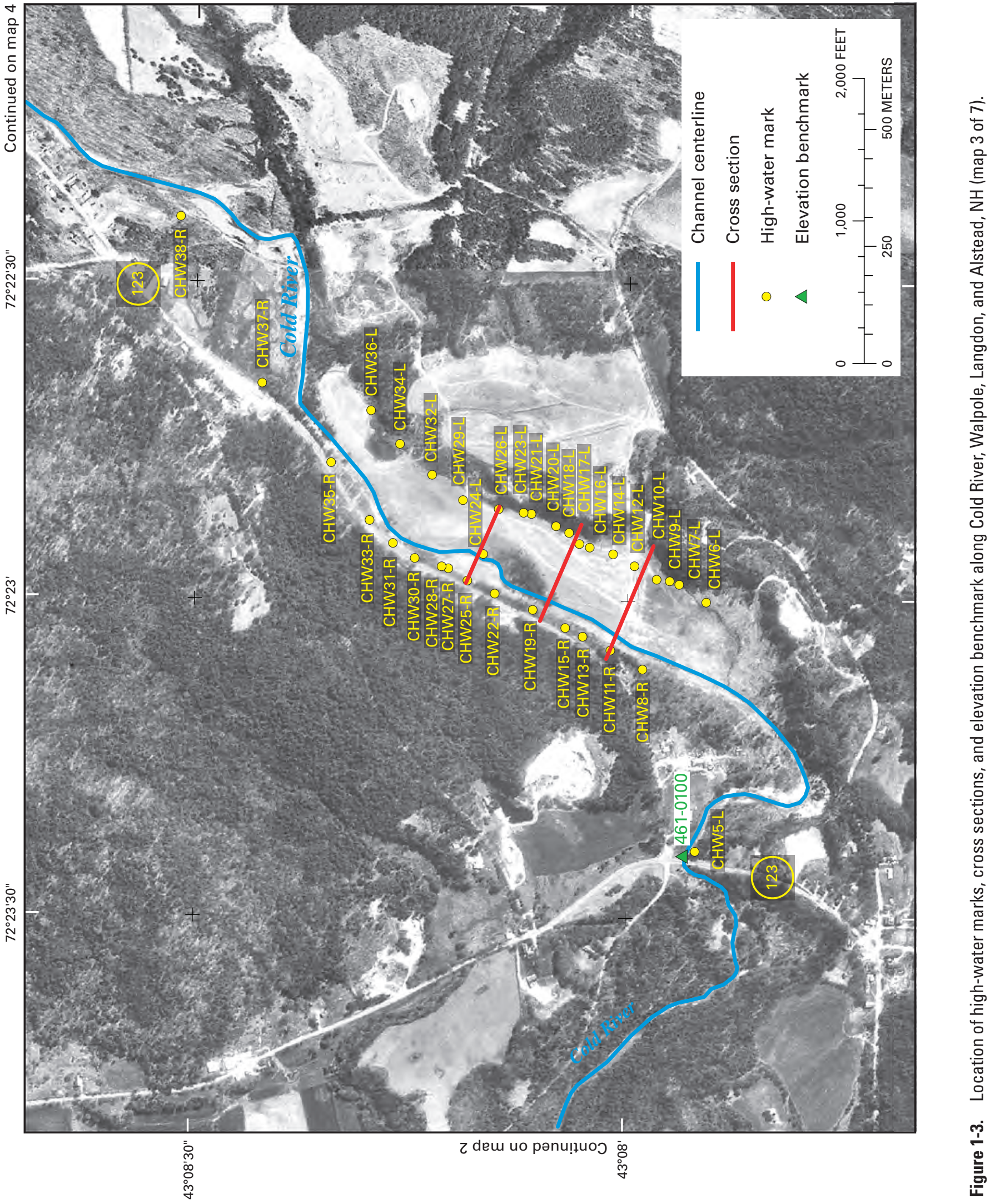




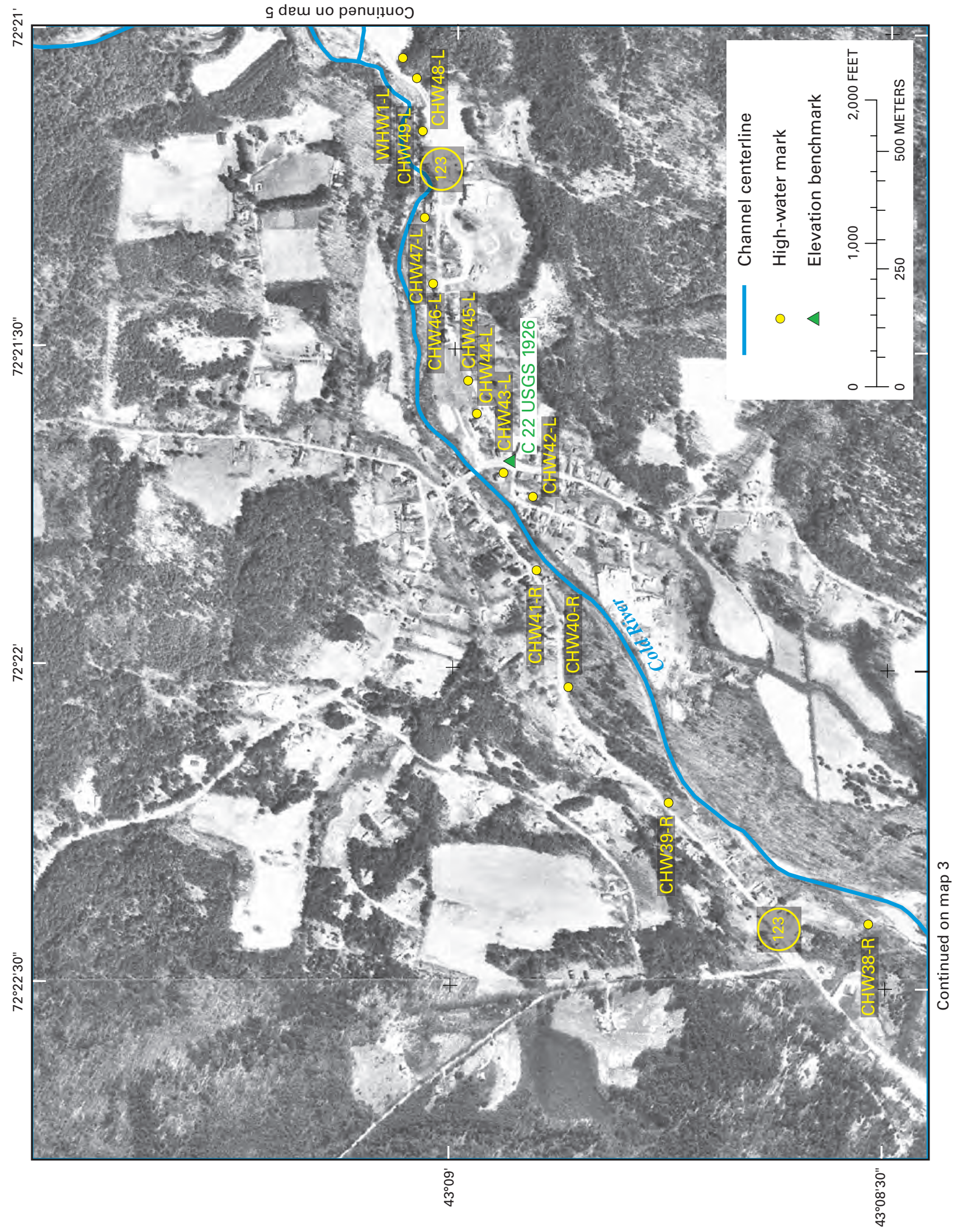

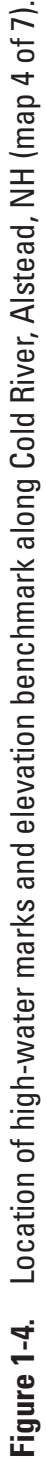




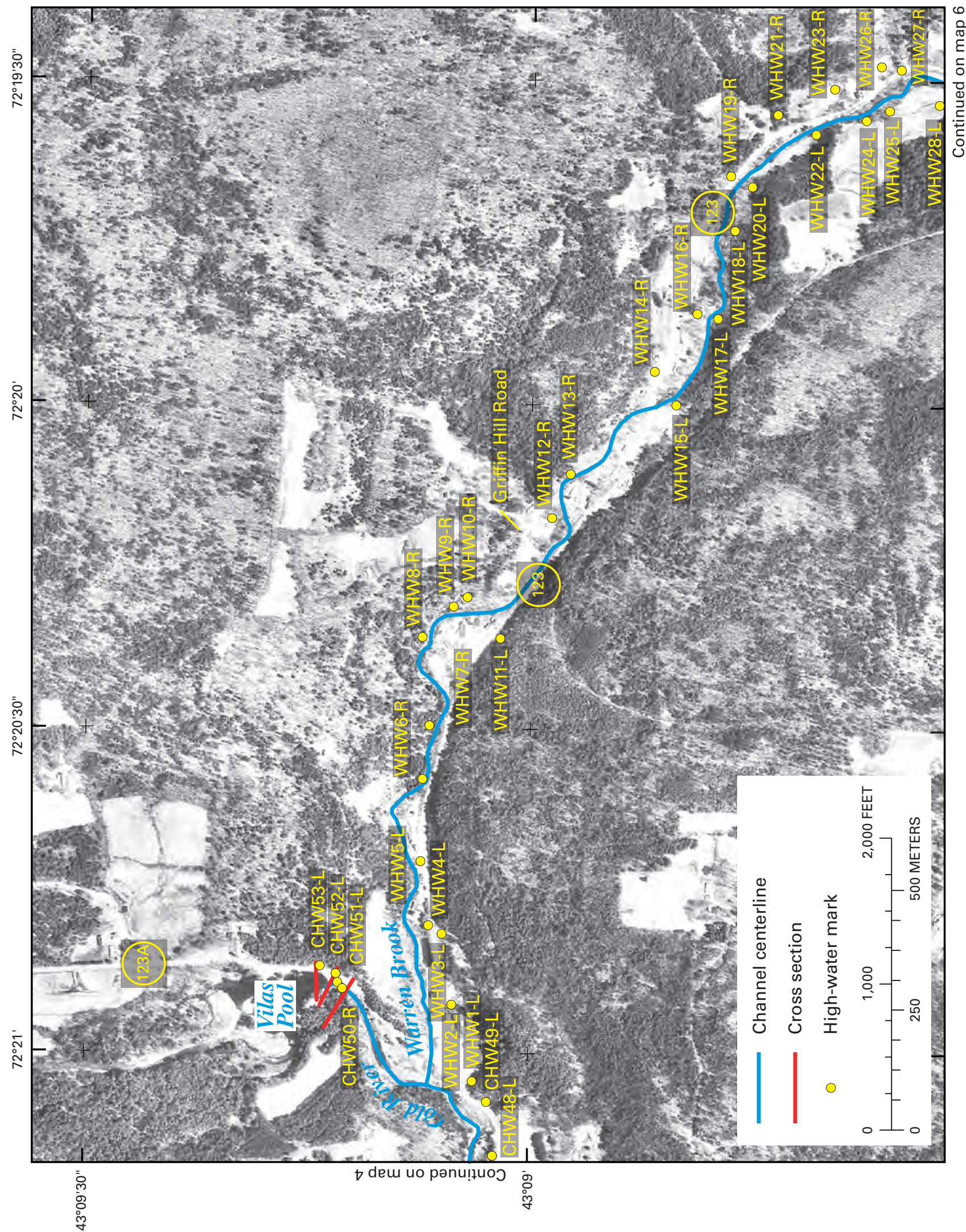




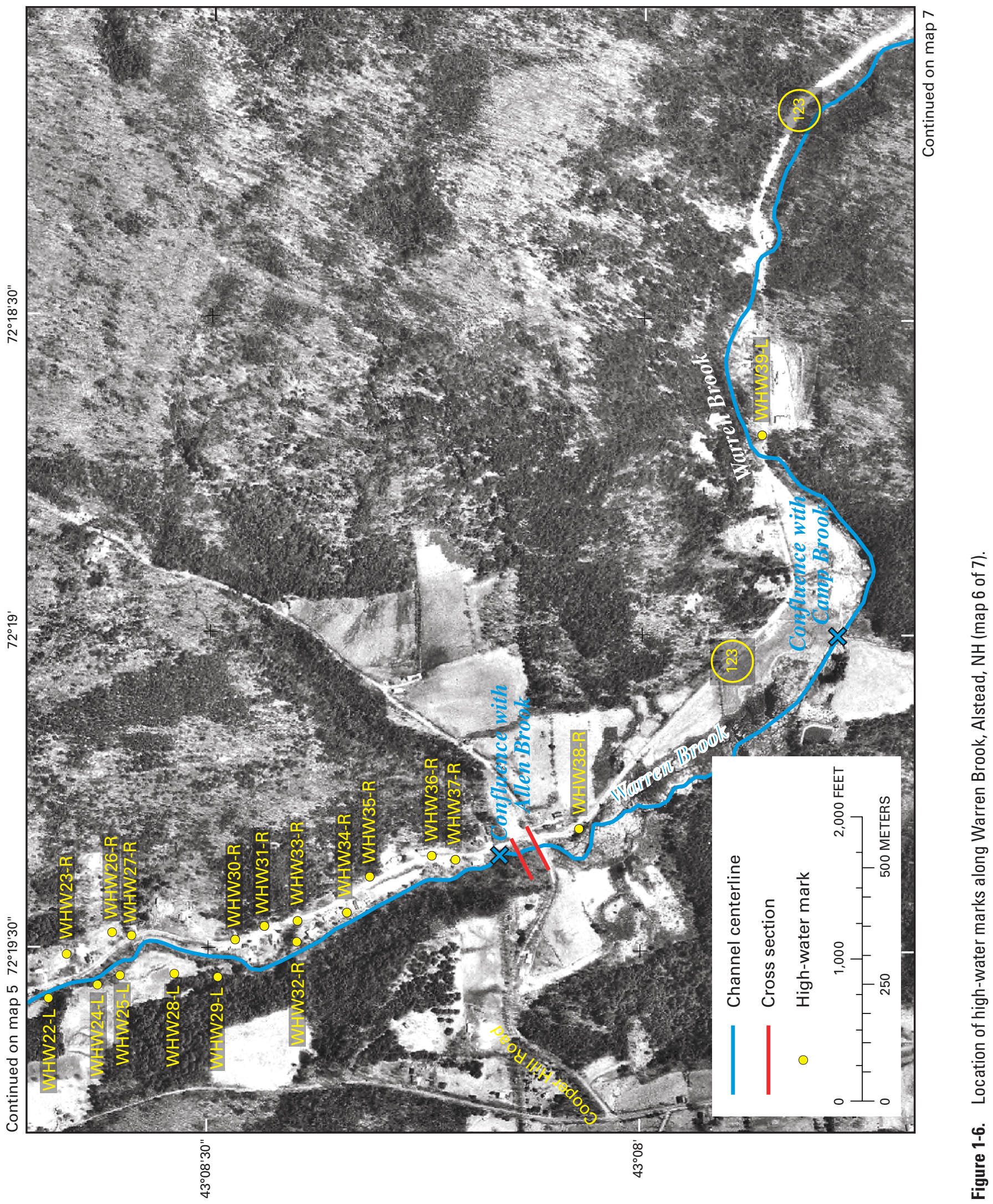




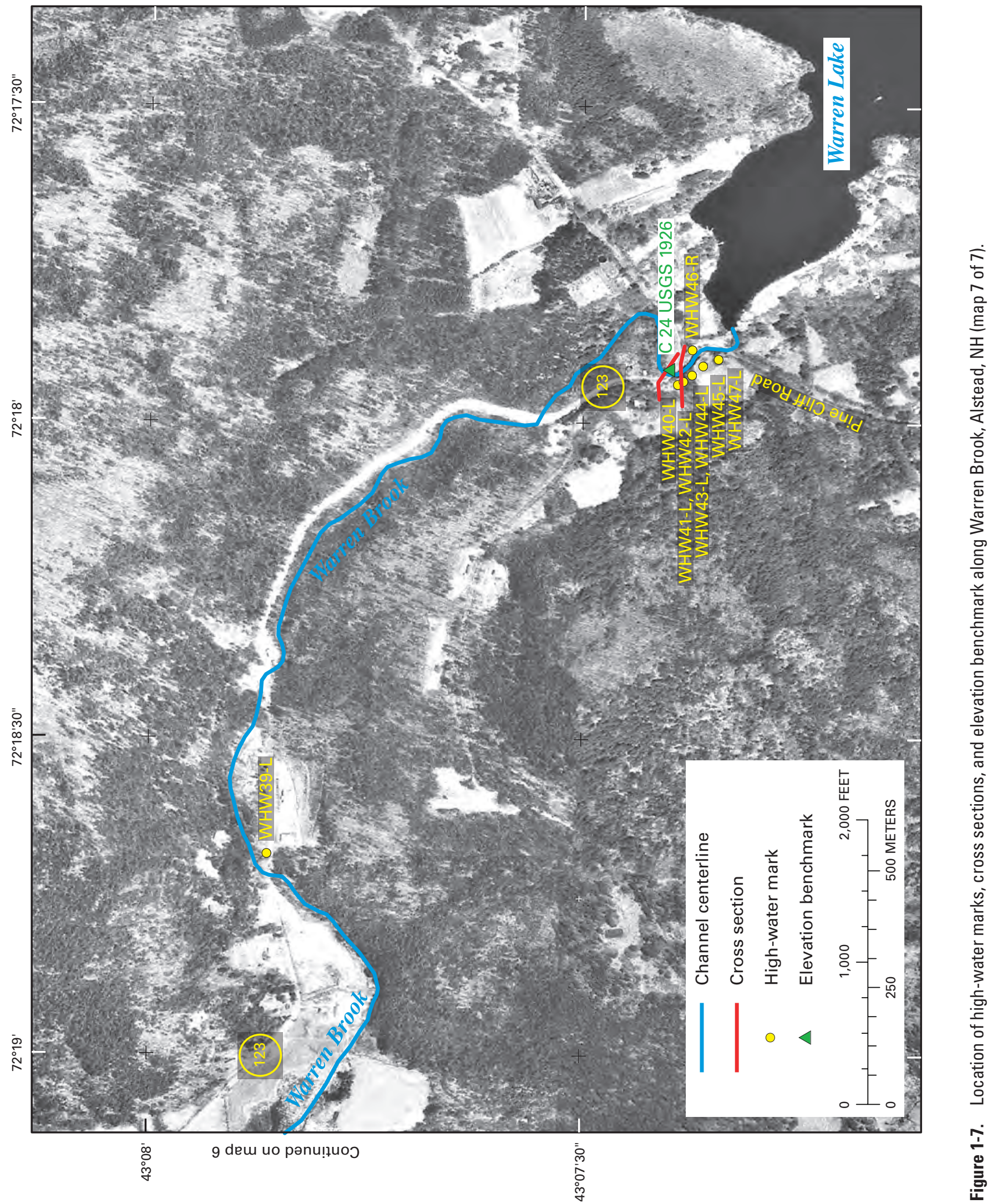




\section{Appendix 2: Profiles of the October 2005 Flood on Cold River and Warren Brook, Southwestern New Hampshire}

Flood profiles in appendix 2 are in order from downstream to upstream. The Cold River flood profile is shown first, followed by the Warren Brook flood profile. 


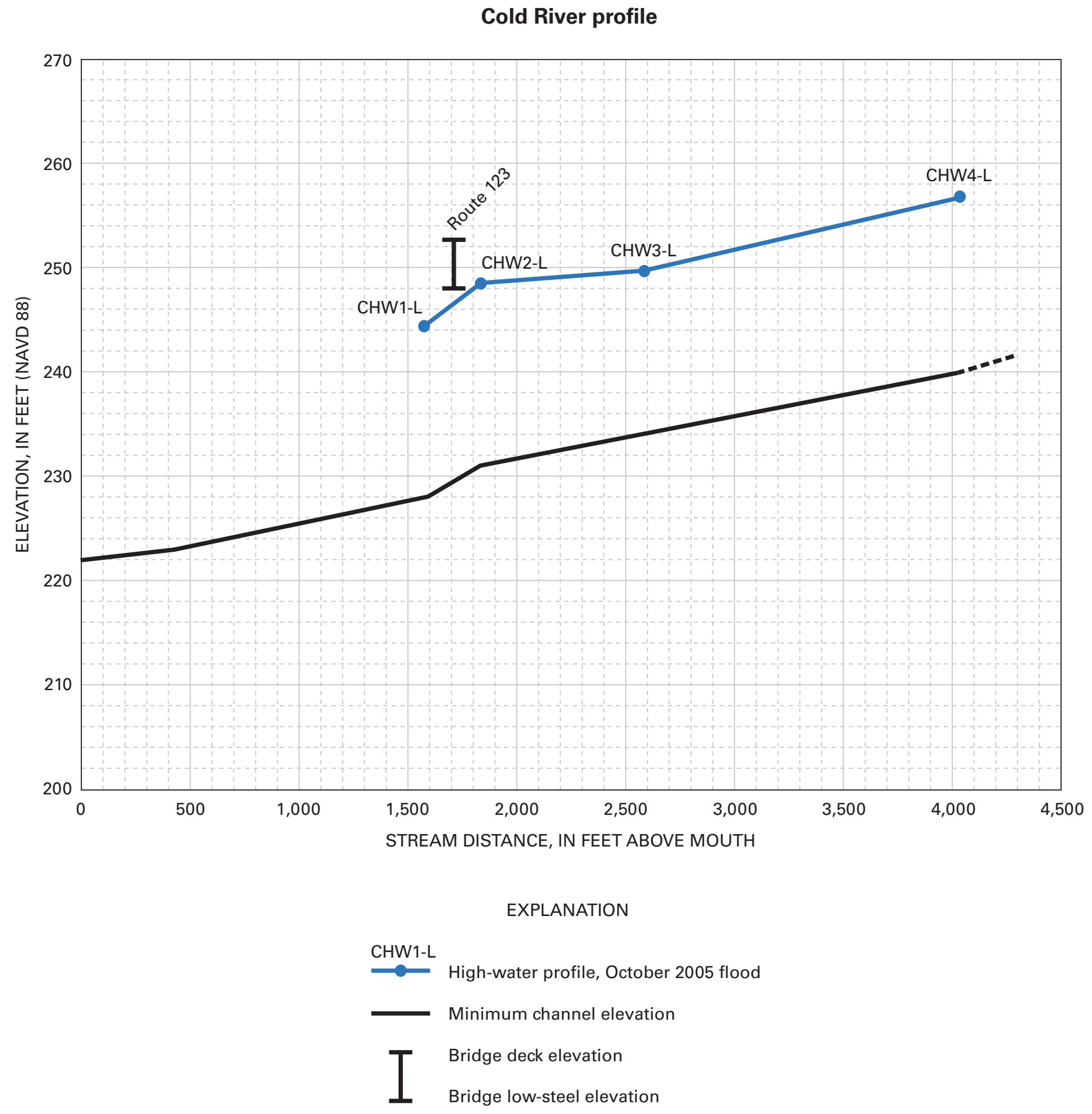

Figure 2-1. Profiles for Cold River, Walpole, NH. 


\section{Cold River profile}

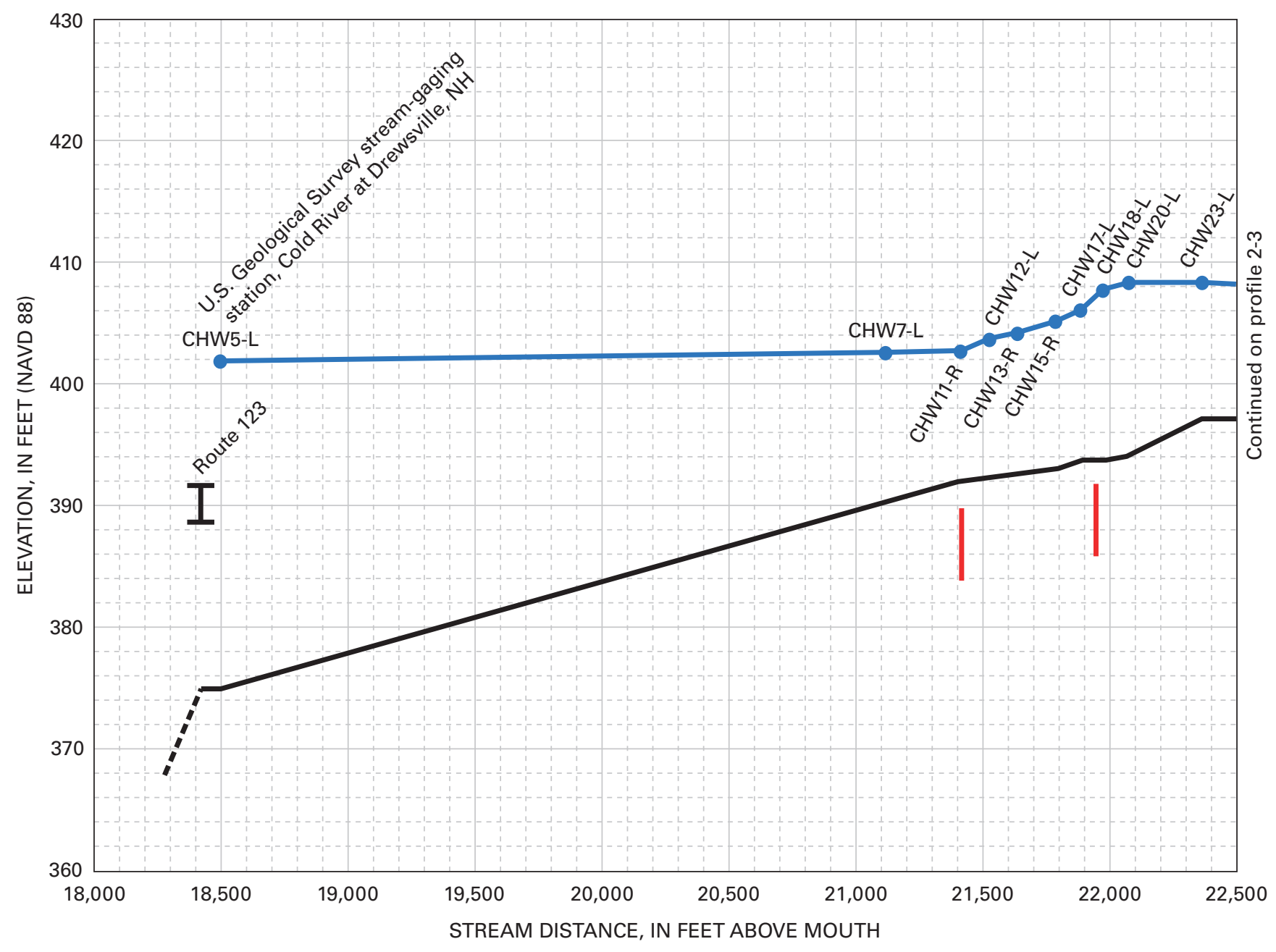

\section{EXPLANATION}

CHW5-L

High-water profile, October 2005 flood

- Minimum channel elevation

Location of cross section shown in figure 1-3

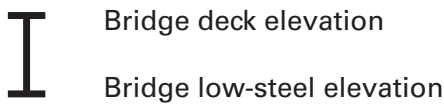

Figure 2-2. Profiles for Cold River, Walpole, and Langdon, NH. 


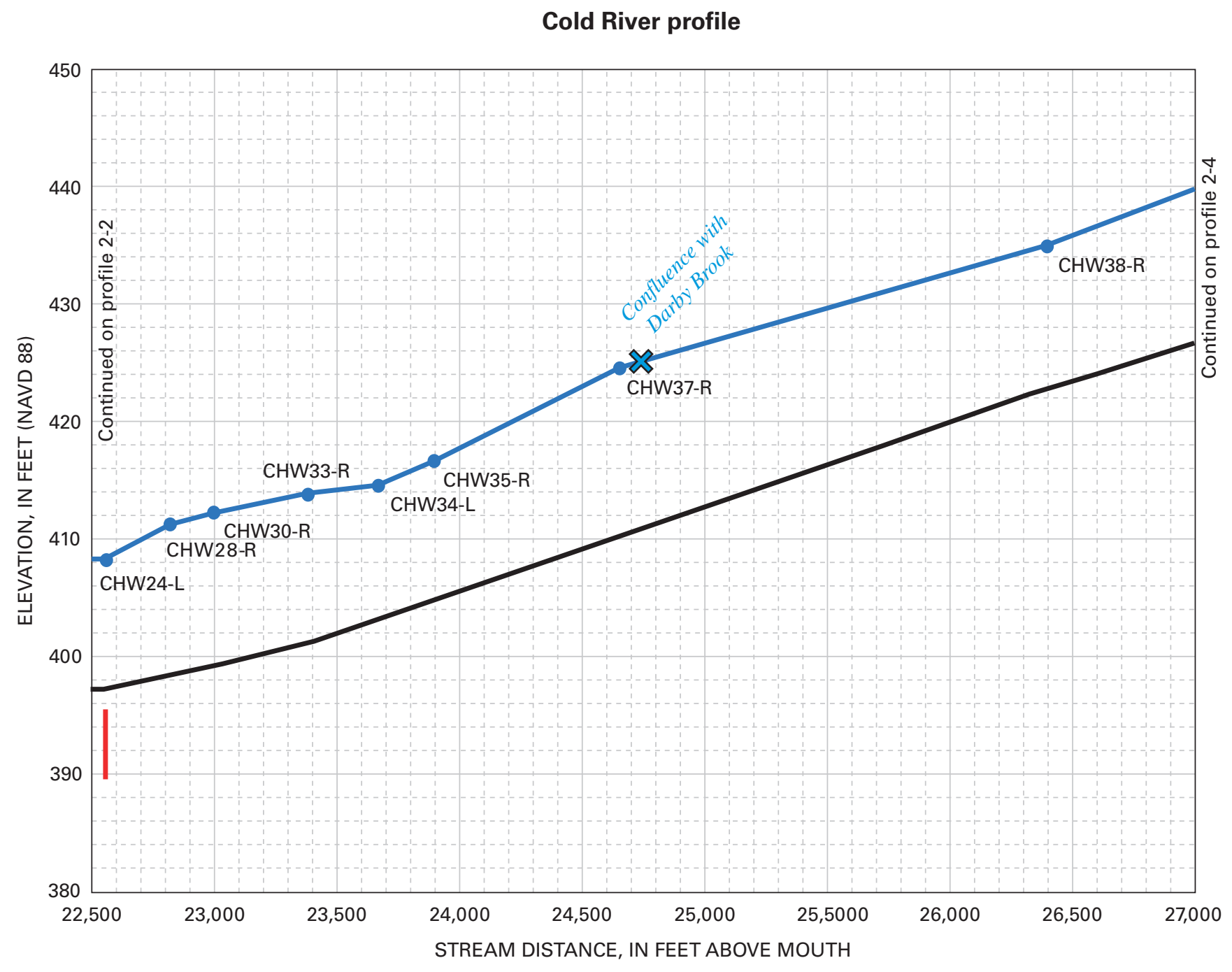

EXPLANATION

CHW24-L

High-water profile, October 2005 flood

Minimum channel elevation

Location of cross section shown in figure 1-3

Figure 2-3. Profiles for Cold River, Langdon and Alstead, NH. 


\section{Cold River profile}

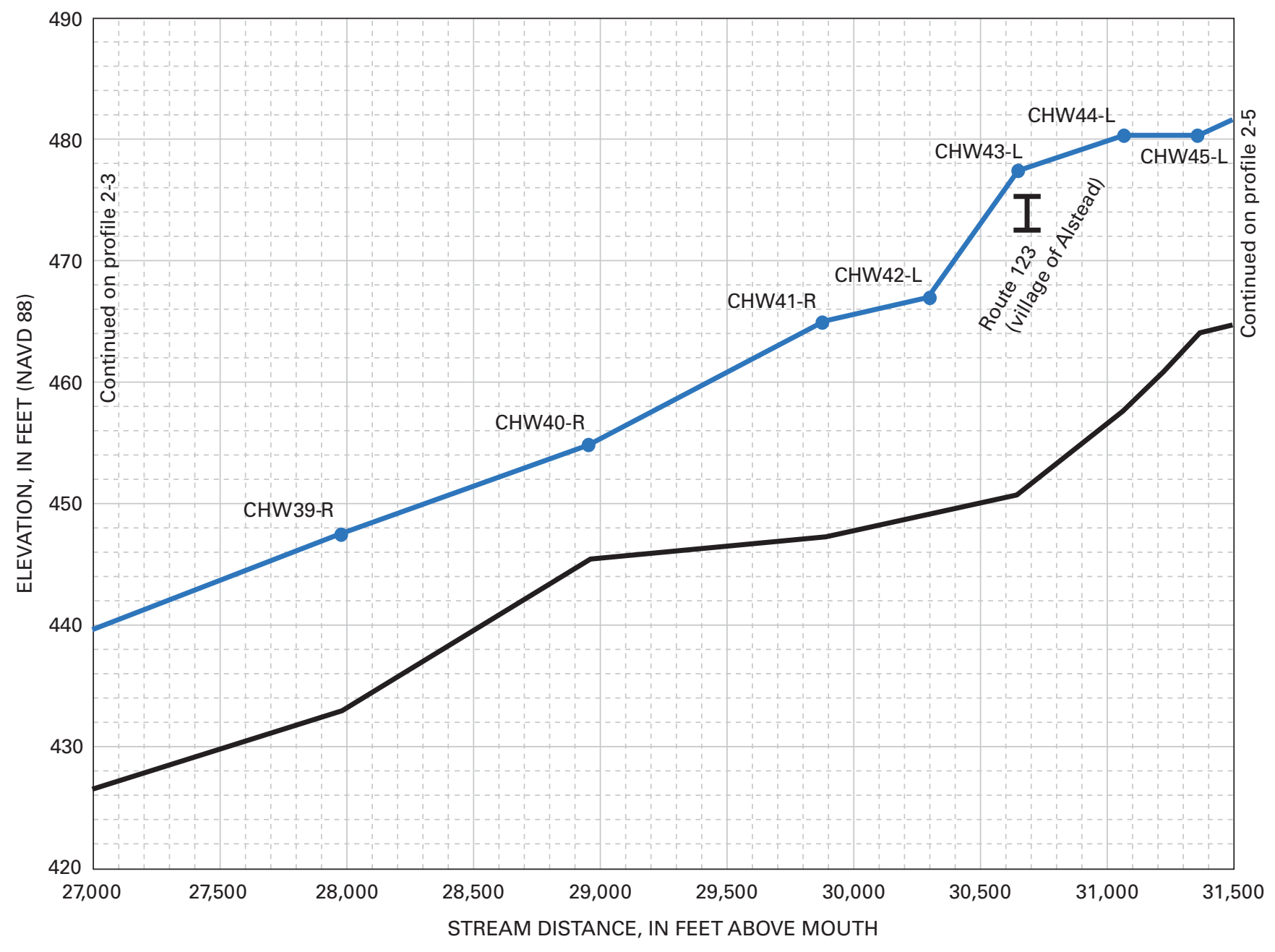

EXPLANATION

CHW39-R

High-water profile, October 2005 flood

Minimum channel elevation

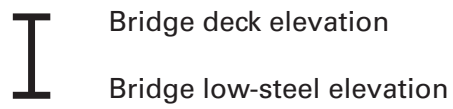

Figure 2-4. Profiles for Cold River, Alstead, NH. 


\section{Cold River profile}

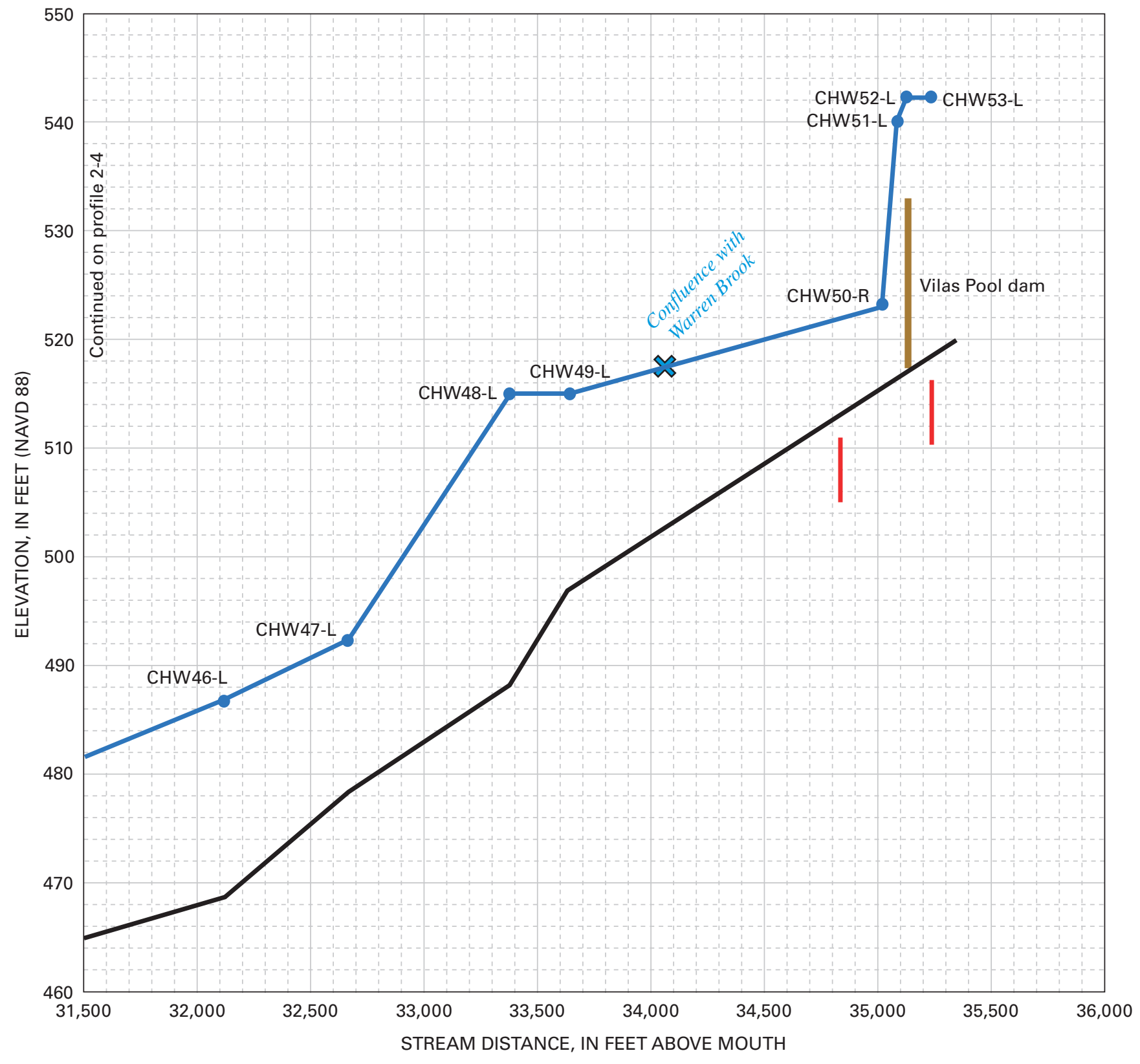

EXPLANATION

CHW46-L

High-water profile, October 2005 flood

Minimum channel elevation

Location of cross section shown in figure 1-5

Figure 2-5. Profiles for Cold River, Alstead, NH. 


\section{Warren Brook profile}

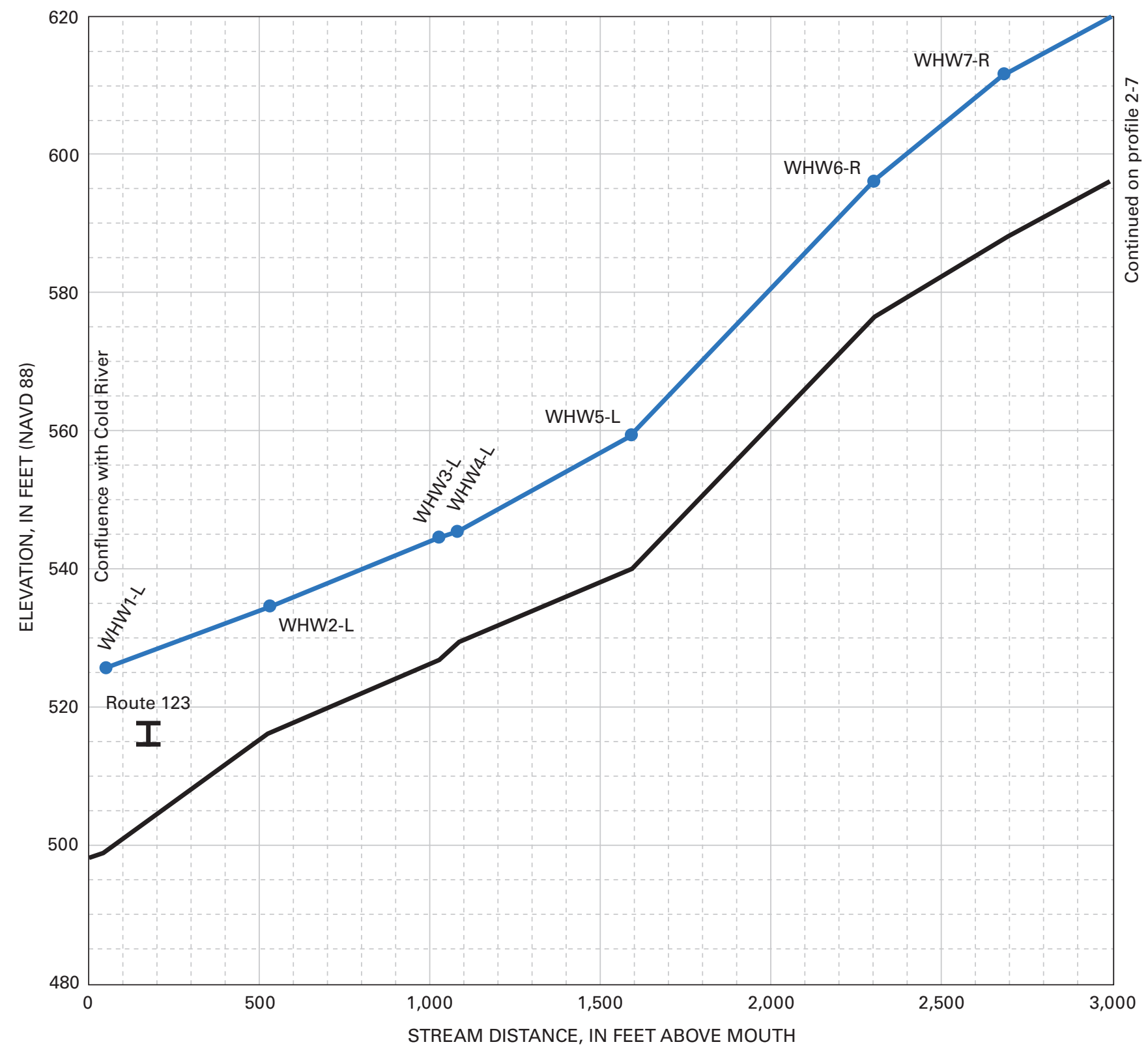

EXPLANATION

WHW1-L

High-water profile, October 2005 flood

Minimum channel elevation

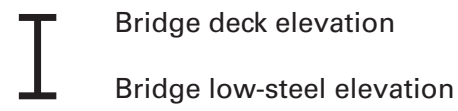

Figure 2-6. Profiles for Warren Brook, Alstead, NH. 


\section{Warren Brook profile}

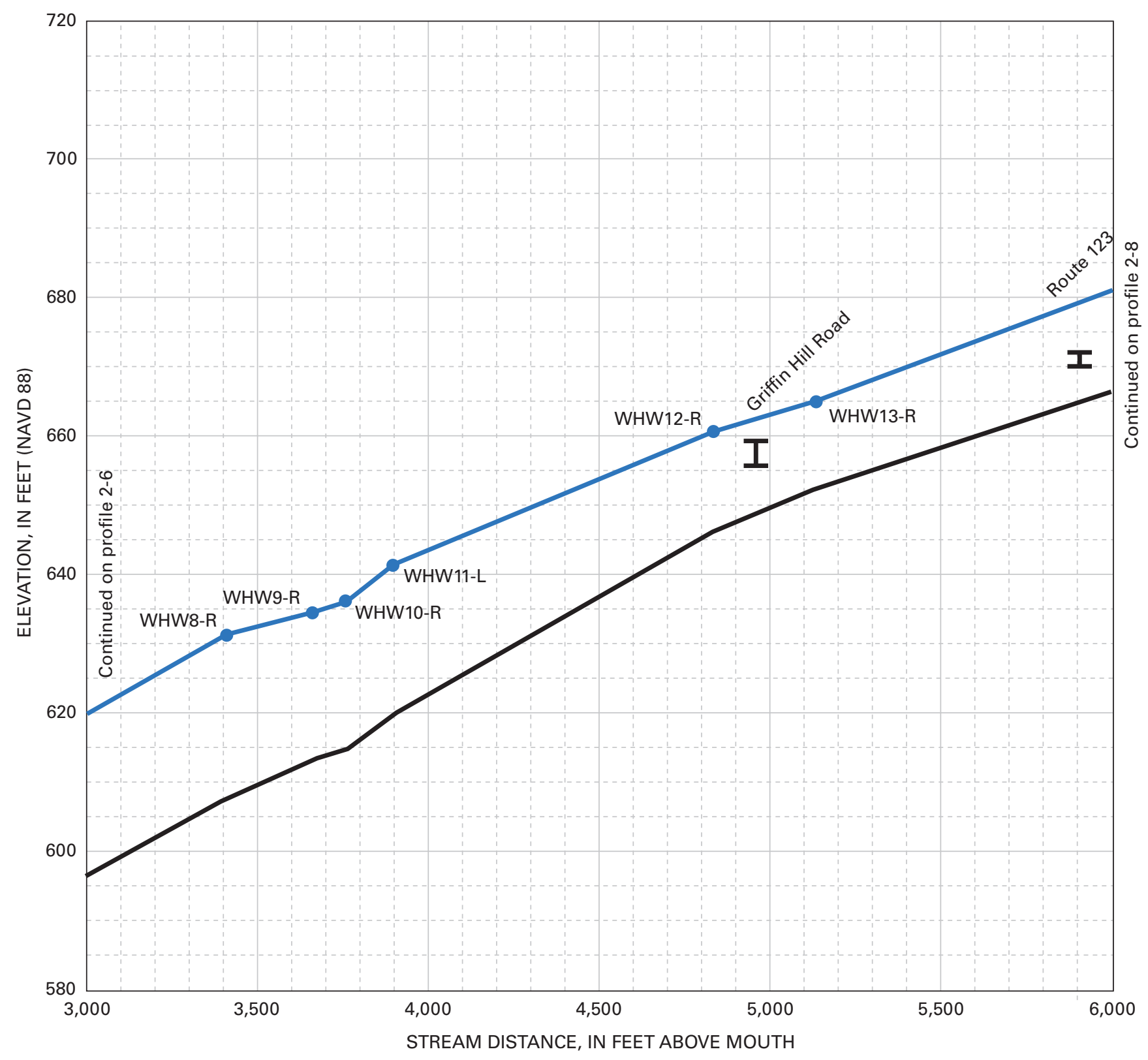

EXPLANATION

WHW8-R

High-water profile, October 2005 flood

Minimum channel elevation

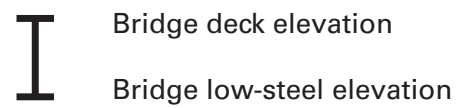

Figure 2-7. Profiles for Warren Brook, Alstead, NH. 


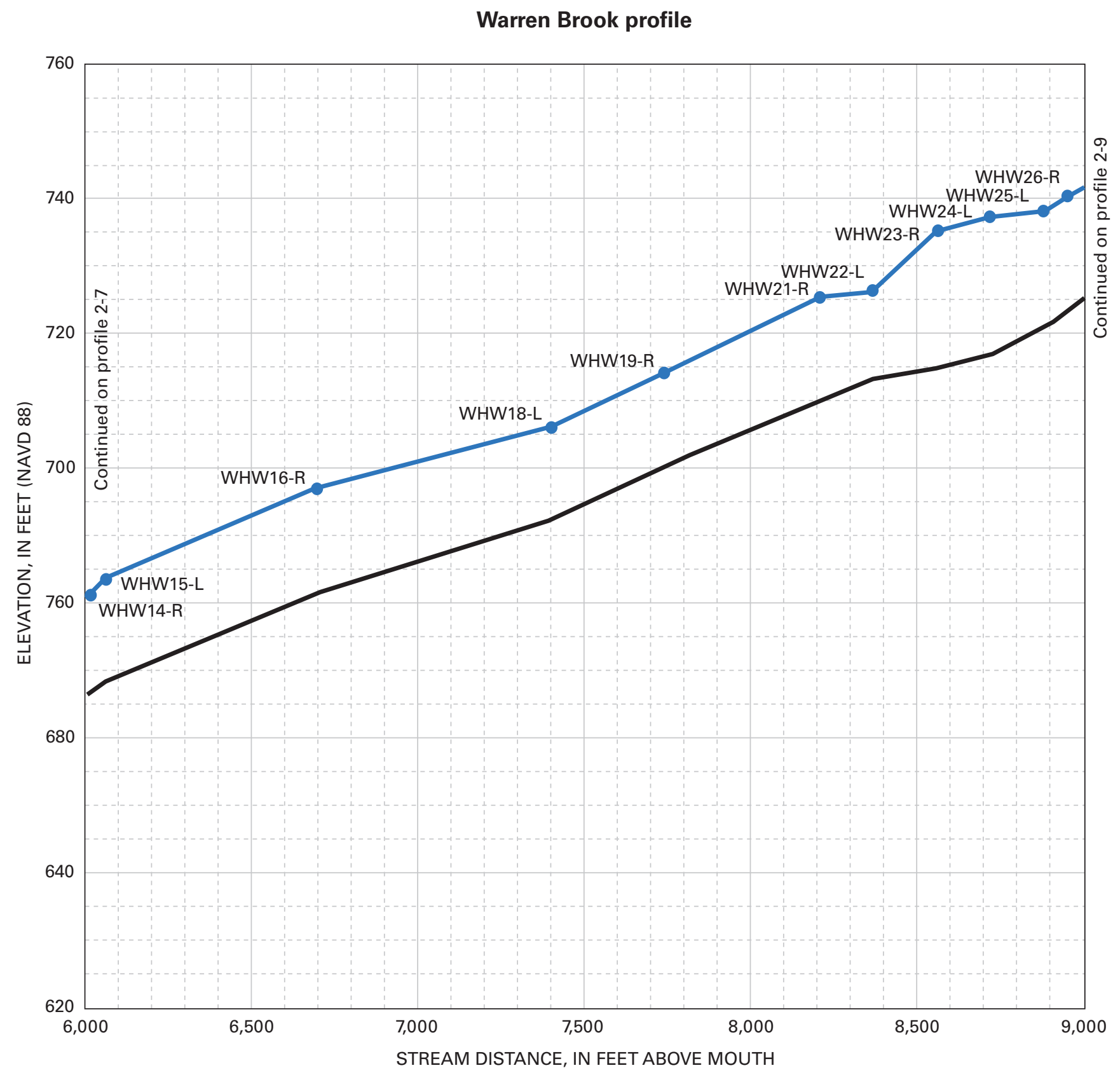

EXPLANATION

WHW14-R

High-water profile, October 2005 flood

Minimum channel elevation

Figure 2-8. Profiles for Warren Brook, Alstead, NH. 


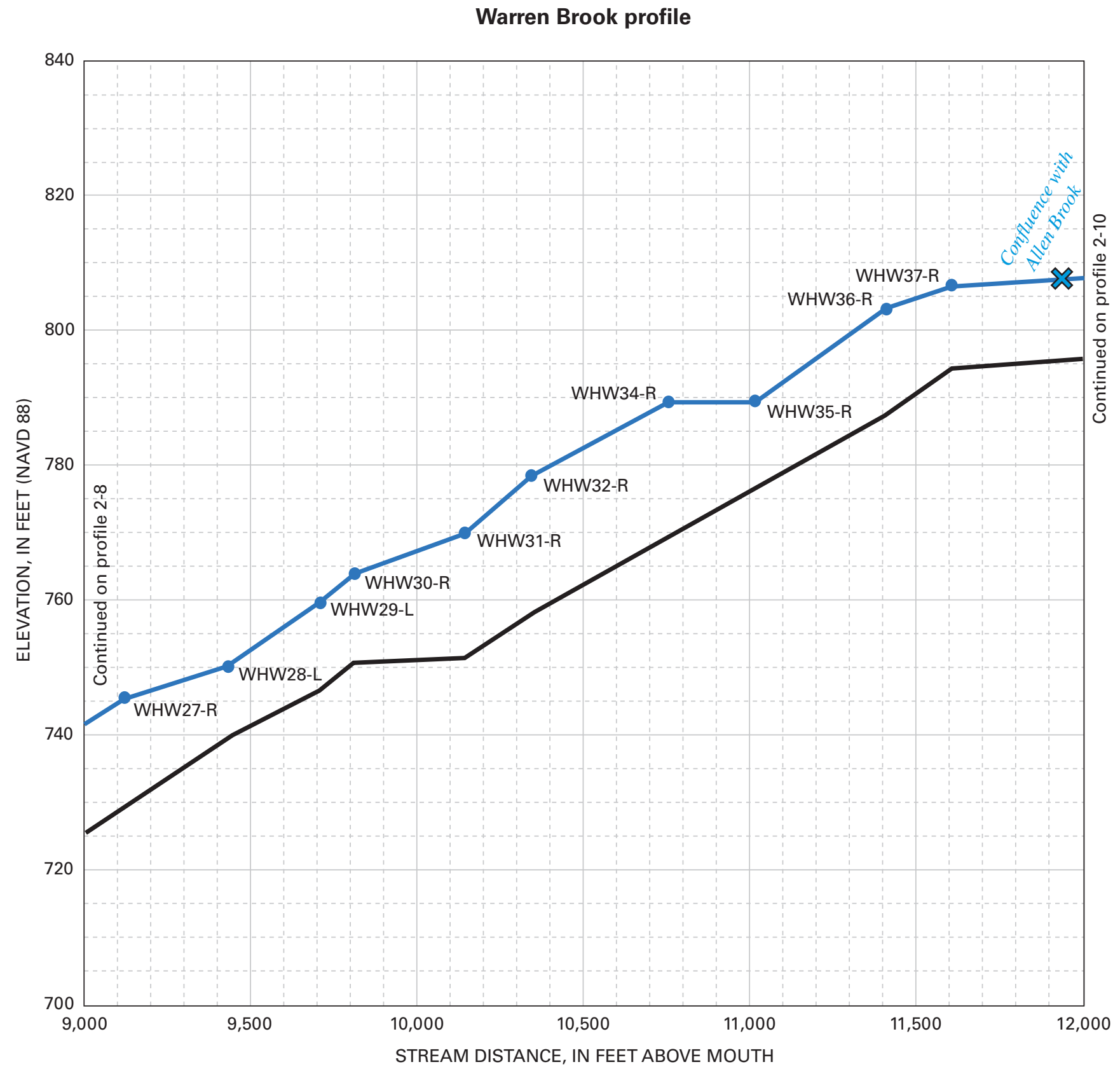

EXPLANATION

WHW27-R

High-water profile, October 2005 flood

Minimum channel elevation

Figure 2-9. Profiles for Warren Brook, Alstead, NH. 


\section{Warren Brook profile}

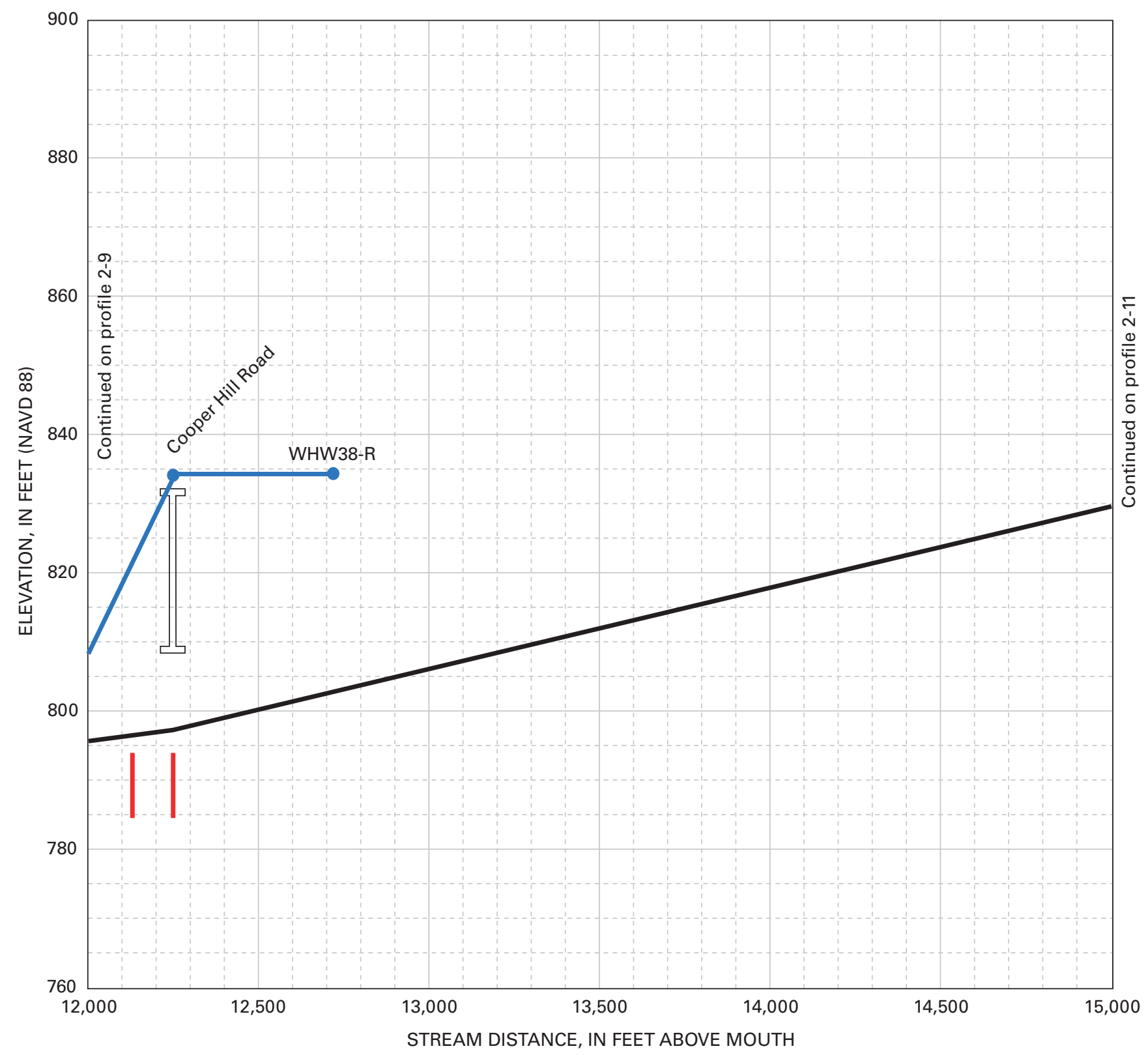

\section{EXPLANATION}

WHW38-R

High-water profile, October 2005 flood

Minimum channel elevation

Location of cross section shown in figure 1-6

$\sqrt{\text { Road elevation }} \begin{aligned} & \text { Top of culvert } \\ & 5\end{aligned}$

Figure 2-10. Profiles for Warren Brook, Alstead, NH. 
Warren Brook profile

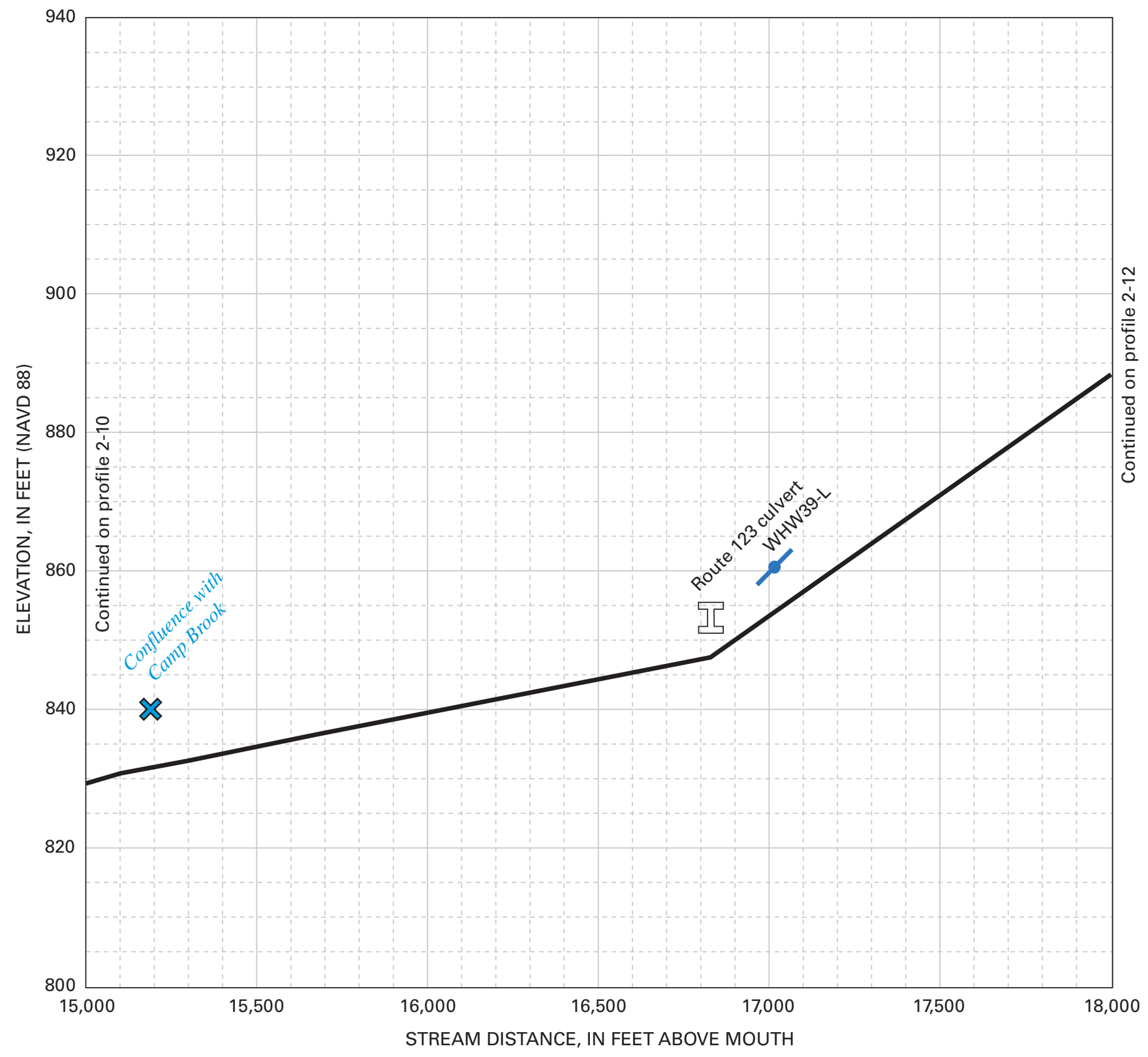

\section{EXPLANATION}

WHW39-L

High-water profile, October 2005 flood

Minimum channel elevation

$\sqrt{\text { Road elevation }} \begin{aligned} & \text { Top of culvert }\end{aligned}$

Figure 2-11. Profiles for Warren Brook, Alstead, NH. 


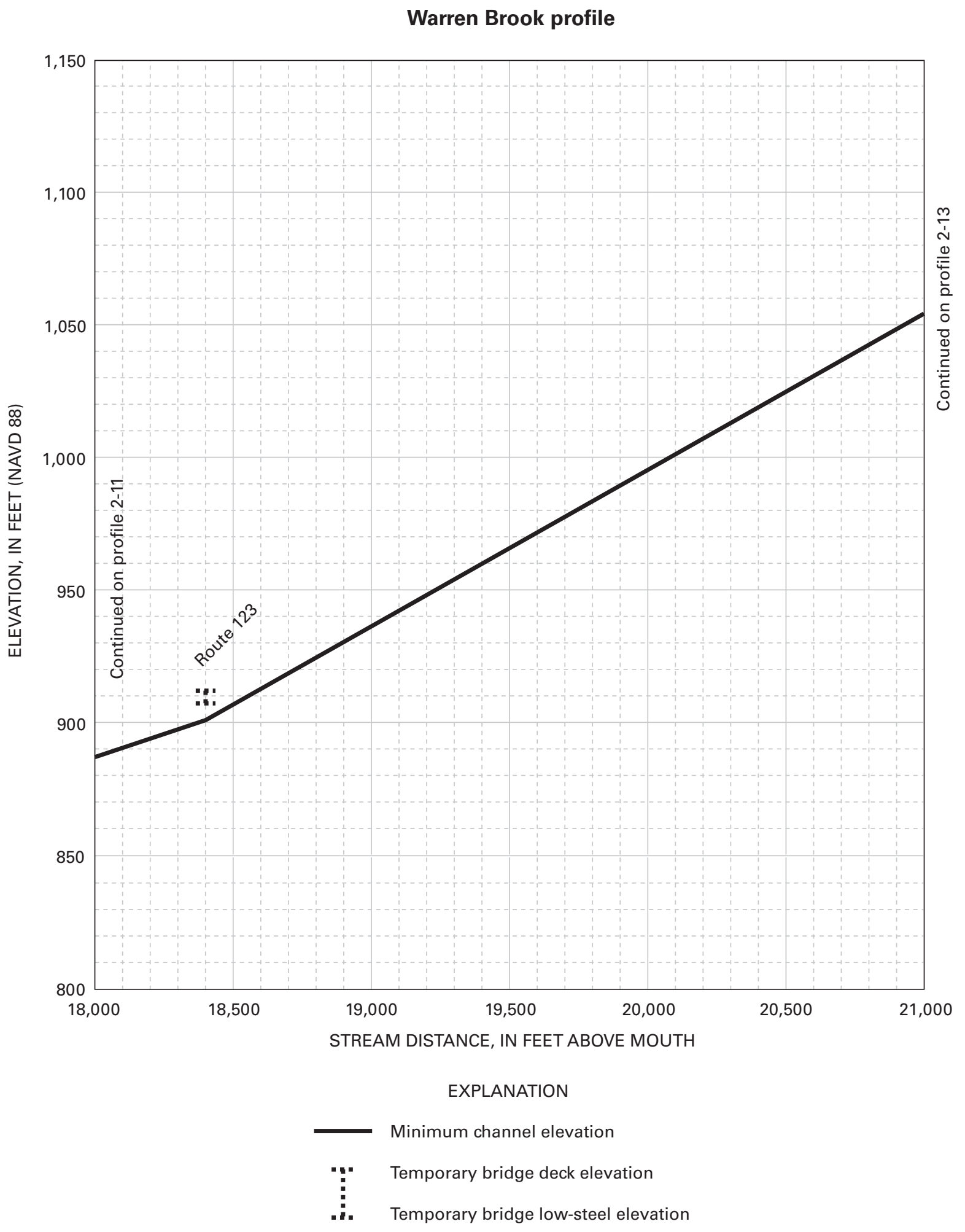

Figure 2-12. Channel profile for Warren Brook, Alstead, NH. 

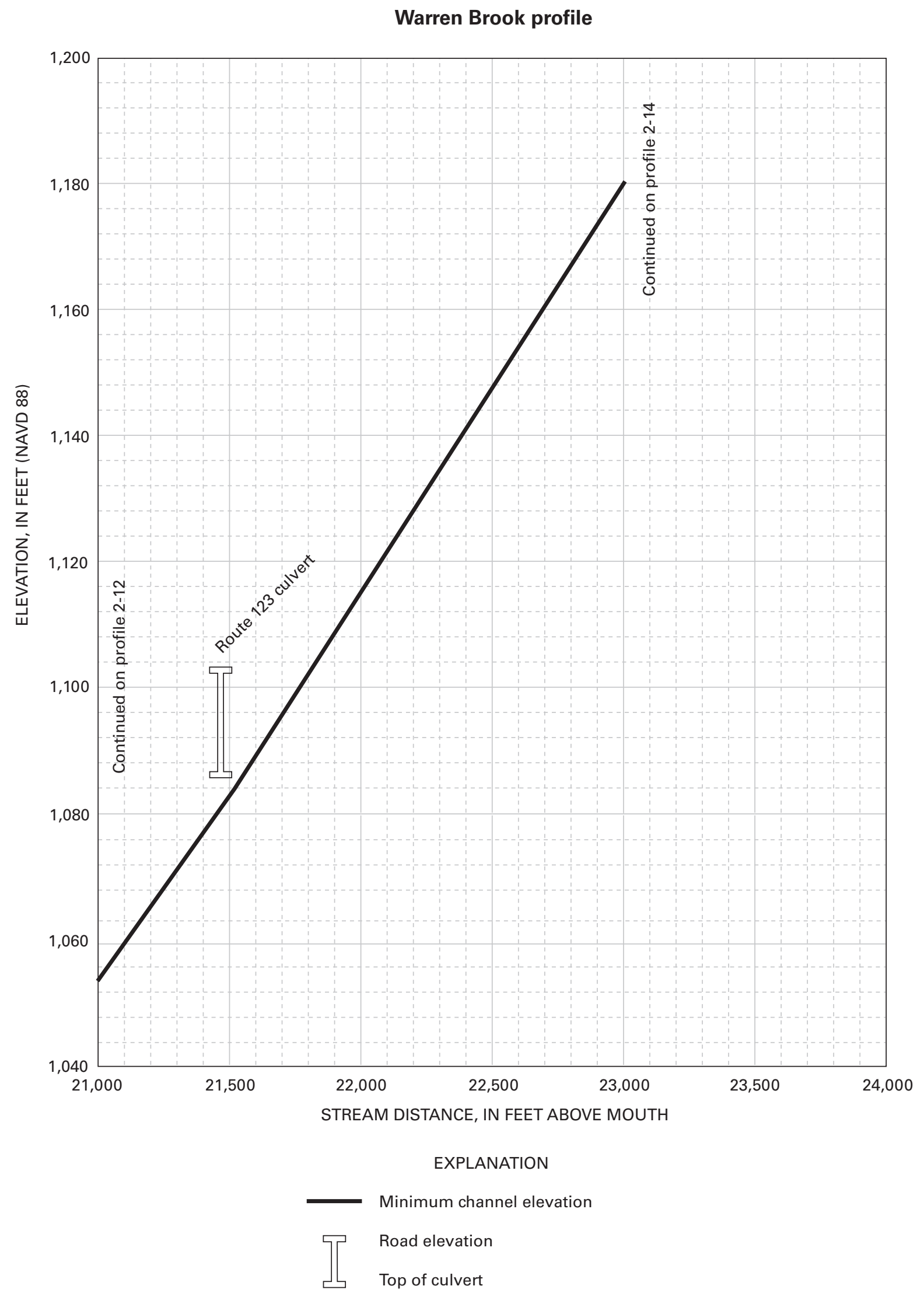

Figure 2-13. Channel profile for Warren Brook, Alstead, NH. 


\section{Warren Brook profile}

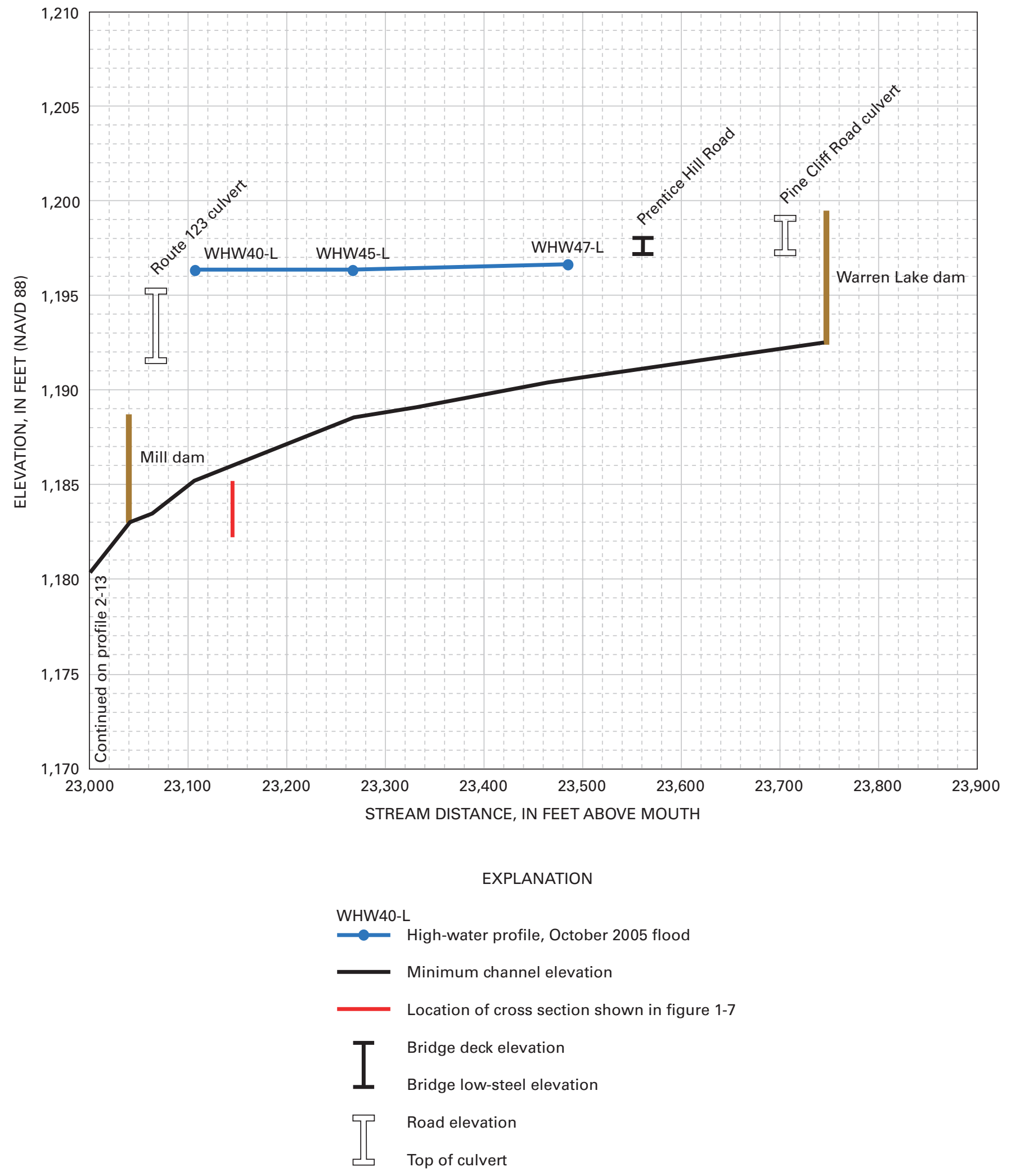

Figure 2-14. Profiles for Warren Brook, Alstead, NH. 


\section{Appendix 3: Elevation Benchmarks Along Cold River and Warren Brook, New Hampshire}


Table 3-1. Elevation reference marks along Cold River and Warren Brook.

\begin{tabular}{|c|c|c|}
\hline Designation & $\begin{array}{l}\text { Elevation, } \\
\text { feet } \\
\text { (NAVD 88) }\end{array}$ & Description \\
\hline C 22 USGS 1926 & 477.28 & $\begin{array}{l}\text { Standard USGS Disk stamped "C } 22 \text { 1926" set in the north concrete curb of the grass triangle formed by } \\
\text { the road junctions of State Routes 12-A and } 123 \text { and Hill Road in Alstead, NH. }\end{array}$ \\
\hline C 24 USGS 1926 & $1,190.35$ & $\begin{array}{l}\text { Standard USGS Disk stamped "C } 24 \text { 1926" set in a concrete dam and foundation to an old grist mill } \\
\text { (circa 1767) } 40 \text { feet north from the center of State Route } 123 \text { and } 525 \text { feet northwest of the outlet of } \\
\text { Warren Lake, Alstead, NH. }\end{array}$ \\
\hline
\end{tabular}

\footnotetext{
${ }^{1}$ North American Vertical Datum of 1988.
} 
Prepared by Publications Service Center 1

For more information concerning the research in this report, contact: Keith W. Robinson, Director

U.S. Geological Survey

New Hampshire-Vermont Water Science Center

361 Commerce Way

Pembroke, NH 03275

or visit our Web site at:

http://nh.water.usgs.gov 
